\title{
AVALIAÇÃO NA APRENDIZAGEM DA EDUCAÇÃO INFANTIL: UM ESTUDO DE CASO NO MUNICÍPIO DE PRESIDENTE KENNEDY-ES
}

\section{ARTIGO ORIGINAL}

GOMES, Hilda Angélica Lima Fontana ${ }^{1}$

GUISSO, Luana Frigulha ${ }^{2}$

GOMES, Hilda Angélica Lima Fontana. GUISSO, Luana Frigulha. Avaliação na aprendizagem da Educação Infantil: Um estudo de caso no Município de Presidente Kennedy-ES. Revista Científica Multidisciplinar Núcleo do Conhecimento. Ano 05, Ed. 06, Vol. 09, pp. 94-134. Junho de 2020. ISSN: 2448-0959, Link de acesso: https://www.nucleodoconhecimento.com.br/educacao/avaliacao-naaprendizagem

\section{RESUMO}

Este artigo tem como objeto a avaliação da aprendizagem na Educação Infantil no município de Presidente Kennedy-ES. Etapa do primeiro contato da criança com o universo escolar, quando ela inicia sua vivência com o conhecimento sistematizado, a Educação Infantil integra a Educação Básica brasileira desde 1996, por determinação da Lei no 9.394/1996 (Lei de Diretrizes e Bases da Educação Nacional - LDB). Nesse contexto, a presente pesquisa entende ser necessário a realização do

\footnotetext{
${ }^{1}$ Mestrado em Ciência, Tecnologia e Educação (Faculdade Vale do Cricaré - FVC), Pós-Graduação em Educação Infantil (Faculdade de Tecnologia São Francisco) e Graduação em Pedagogia (Universidade de Uberaba).

2 Doutoranda em História Social das Relações Políticas (Universidade Federal do Espírito Santo - UFES), Mestrado em Tecnologia Ambiental (Faculdade de Ciências Humanas de Aracruz), Especialização em Psicopedagogia (Faculdade de Ciências Humanas de Aracruz) e Graduação em Pedagogia (Faculdade de Ciências Humanas de Aracruz).
} 
debate a respeito da avaliação na Educação Infantil, assim como a recuperação de seu sentido pedagógico, enquanto meio de diagnóstico capaz de oferecer subsídios para o desenvolvimento do educando e para a garantia de seus direitos, com a realização da devida intervenção pedagógica quando este desenvolvimento não se dá de modo espontâneo. Com o objetivo geral de compreender a percepção das professoras da Educação Infantil da Rede Municipal de Presidente Kennedy-ES, especialmente as da Pré-escola, sobre os instrumentos avaliativos utilizados para fins de acompanhamento do desenvolvimento do aluno, a pesquisa utilizou uma metodologia baseada na realização de grupo focal e observações diretas in loco das escolas. Como resultado, concluiu-se que as professoras pesquisadas apresentam dificuldades para refletir sobre os instrumentos avaliativos utilizados, o que desestimula a busca pela diversificação e inovação em relação às formas de avaliação na Educação Infantil. Para ajudar a solucionar este problema, a pesquisa propõe a realização de um projeto de formação continuada para que as professoras da Educação Infantil compreendam a importância da avaliação escolar e suas particularidades na Educação Infantil.

Palavras-chave: Avaliação da Aprendizagem, Educação Infantil, Presidente Kennedy.

\section{INTRODUÇÃO}

A temática da avaliação da aprendizagem na Educação Infantil chama a atenção pela compreensão que os profissionais da Educação possuem sobre o modo de avaliar e de como avaliar nesta etapa educacional. Sendo a Educação Infantil a primeira etapa da Educação Básica, o tema da avaliação escolar pode ser discorrido, inicialmente, a partir da compreensão da avaliação em Luckesi (1996, p. 180), para quem o "ato de avaliar, por sua constituição mesma, não se destina a um julgamento 'definitivo' sobre alguma coisa, pessoa ou situação", não sendo, portanto, um ato seletivo. Para o educador, a avaliação escolar destina-se, antes de tudo, ao diagnóstico, isto é, a constatação e a qualificação do estado de alguma coisa, que possa servir como base para uma decisão, podendo esta se dar, por exemplo, no sentido de estratégia de intervenção pedagógica. 
Desta forma, com o passar do tempo, a avaliação escolar acabou assumindo a prática de provas ou exames, o que, para Luckesi (1996), gerou um desvio no seu uso ao tornar-se "um meio para classificar os educandos e decidir sobre os seus destinos no momento subsequente de suas vidas escolares" (LUCKESI, 1996, p. 196). Assim, em consequência deste tipo de uso, a avaliação escolar tornou-se um instrumento de poder e um recurso para o exercício da autoridade e do controle do professor, muitas vezes com finalidade muito mais disciplinar que pedagógica.

Diante desta questão, torna-se necessário a realização do debate a respeito da avaliação e a recuperação de seu sentido pedagógico, enquanto meio de diagnóstico capaz de oferecer subsídios para o desenvolvimento do educando e para a garantia de seus direitos, com a realização da devida intervenção pedagógica quando este desenvolvimento não se dá de modo espontâneo.

Quando se fala de intervenção pedagógica aqui, refere-se à interferência que um profissional da educação faz sobre o processo de desenvolvimento ou aprendizagem no momento em que o indivíduo apresenta dificuldades de continuidade ou progressão. Nesse sentido, entende-se que, durante a intervenção pedagógica, o procedimento adotado interfere no processo, promovendo uma espécie de correção de rumos. Desta forma, parte-se do pressuposto da necessidade de introdução de novos elementos para que o indivíduo, no caso da Educação Infantil, a criança de 0 a 5 anos, pense, elabore e compreenda de uma maneira diferenciada. No caso deste trabalho, em particular, a mesma recairá sobre a segunda etapa da Educação Infantil, a Pré-Escola, que atende a crianças de 4 a 5 anos.

Assim, é importante destacar que a Educação Infantil trabalha com um perfil de aluno diferenciado, ainda no início do processo de formação humana, no qual a dimensão afetiva e emocional, além da dependência dos adultos, é muito mais relevante. É por isso, então, que as estratégias avaliativas para esta etapa da educação também são diferenciadas, com a priorização da utilização da observação, do registro e da reflexão sobre a aplicação de provas e exames. 
Isso significa que, se bem trabalhada, a avaliação na Educação Infantil pode se constituir num instrumento fundamental de garantia dos direitos de aprendizagem e de desenvolvimento das crianças de 0 a 5 anos de idade, atendendo tanto ao que está estipulado pela legislação[3] quanto aos parâmetros e metas de qualidade estabelecidos pelo Ministério da Educação[4] e que devem ser seguidos por todas as redes de ensino brasileiras, incluindo as redes municipais.

Neste aspecto, cabe destacar que se vive um momento em que os sistemas e redes de ensino no Brasil devem adequar seus respectivos currículos à Base Nacional Comum Curricular (BNCC)[5] com o objetivo de garantir o conjunto de aprendizagens essenciais, definido pela BNCC, que todos os estudantes devem desenvolver ao longo das etapas e modalidades da Educação Básica. Nesse contexto, considerando que a avaliação escolar é a grande responsável pelo monitoramento e a verificação das aprendizagens; considerando que, a partir de agora, a BNCC passará a nortear os currículos dos sistemas e redes de ensino de todo o país; e considerando que a Rede Municipal de Educação de Presidente Kennedy-ES já está em processo de discussão sobre a implementação da mesma; este artigo pretende contribuir para a recuperação do debate sobre a avaliação na Educação Infantil na referida rede municipal capixaba, subsidiando, com a pesquisa apresentada, a discussão sobre a aplicação da BNCC naquela rede. $\mathrm{O}$ artigo pretende ainda contribuir para a recuperação da reflexão sobre o sentido pedagógico da avaliação, apresentando, a partir disso, uma proposta de formação continuada para o aprimoramento da formação dos professores da Educação Infantil da Rede Municipal de Presidente Kennedy.

Para tanto, a pesquisa que gerou o presente artigo lançou mão do seguinte problema: qual a compreensão das professoras da Educação Infantil, particularmente as da Préescola, da Rede Municipal de Presidente Kennedy-ES sobre a avaliação nesta etapa da Educação Básica?

A questão explicitada buscou atender a um objetivo geral e a três objetivos específicos. O objetivo geral é: compreender a percepção das professoras da Educação Infantil, especialmente as da Pré-escola, sobre os instrumentos avaliativos utilizados para fins de acompanhamento do desenvolvimento do aluno. 
Os objetivos específicos são: i) identificar quais são e como são utilizados os instrumentos avaliativos na Pré-escola nas EMEIEFs (Escolas Municipais de Educação Infantil e Ensino Fundamental) do município; ii) verificar se os instrumentos avaliativos são eficazes no acompanhamento da evolução individual e coletiva dos alunos da Pré-escola da Rede Municipal; e iii) propor à Secretaria Municipal de Educação de Presidente Kennedy (SEME) uma formação continuada para que as professoras da Educação Infantil e da Pré-escola discutam a importância da definição dos objetivos de avaliação nessa etapa de ensino e a melhor forma de utilização de seus instrumentos na prática educativa.

A metodologia utilizada baseou-se num estudo de caso exploratório com abordagem qualitativa da percepção e prática em relação à avaliação escolar das professoras da Pré-escola da Educação Infantil da Rede Municipal de Educação de Presidente Kennedy. Para efeitos operacionais, o universo foi coberto por meio de observações das escolas e grupo focal com três escolas que oferecem esta etapa educacional.

A escolha de três escolas que oferecem a Pré-escola, que atende a crianças de 4 a 5 anos, se deu pelo baixo número de unidades com esta classificação e pelo pequeno porte do município: Presidente Kennedy é um município localizado no litoral sul capixaba, em um território de 583,932 km² e com população estimada em apenas 11.574 habitantes, em 01 de julho de 2019, pelo Instituto Brasileiro de Geografia e Estatística (IBGE).

No que diz respeito a estruturação, o artigo estará composto por três partes, iniciando por esta introdução. Logo em seguida, na segunda parte, serão apresentados o referencial teórico, a metodologia e os resultados da pesquisa. Finalizando, na terceira parte, será feita a exposição das considerações finais. 


\section{REFERENCIAL TEÓRICO}

\subsection{CONCEITUANDO AVALIAÇÃO DA APRENDIZAGEM}

A denominação avaliação da aprendizagem é atribuída a Ralph Tyler (1902-1994), educador norte-americano que se dedicou à questão de um ensino eficiente e que, no Brasil, é conhecido pelo livro "Princípios básicos de currículo e ensino". Ralph Tyler cunhou a denominação avaliação da aprendizagem na década de 1930 defendendo a ideia da utilização de provas e exames para subsidiar de modo eficiente e mais amplo a prática de ensino. Até então, a avaliação escolar se dava, formalmente, quase exclusivamente através de testes com lápis e papel, o que atribuía ao processo avaliativo o cunho meramente instrumental, além de restrito ao aluno.

A aplicação de testes educacionais partia de uma abordagem positivista e comportamentalista[6], que procurava atribuir um caráter de cientificização e objetivação da educação na época, na tentativa de racionalização e padronização do ensino, buscando mensurar as mudanças comportamentais dos estudantes. A essas mudanças comportamentais, Tyler (1974) chamou de aprendizagem e defendeu que poderiam ser constatadas também através de outros procedimentos avaliativos, tais como testes, escalas de atitude, inventários, questionários e fichas de registros de comportamento. Além disso, o educador defendeu a ampliação do processo de avaliação escolar, incorporando também a dimensão do currículo e dos programas pedagógicos.

De caráter eminentemente quantitativo, esta concepção de avaliação vem exercendo, desde o seu surgimento, forte influência sobre a prática educativa e o cotidiano escolar brasileiro[7], a ponto de ser denominada como "Pedagogia do Exame" (LUCKESI, 1996), por utilizar a avaliação como forma de disciplinamento e controle social dos alunos. O caráter nocivo deste tipo de uso da avaliação escolar, que ainda persiste fortemente na prática educativa do país, está associado ao que Ribeiro (1991) denominou como "Pedagogia da Repetência", para se referir ao fato de que o Brasil é um dos países com as maiores taxas de reprovação do mundo[8]. 
Sob esta perspectiva, autores como Hoffmann (2012) e Luckesi (1996) apontam que a prática escolar usualmente denominada como avaliação tem pouco a ver, de fato, com ela. Isto porque a avaliação escolar ou avaliação da aprendizagem, na verdade, refere-se "a um conjunto de procedimentos didáticos que se estendem por um longo período de tempo e em vários espaços escolares, de caráter processual e visando, sempre, à melhoria do objeto avaliado" (HOFFMANN, 2012, p.13).

Por isso, na concepção destes autores, no âmbito escolar e pedagógico, avaliação é muito mais do que a simples aplicação de provas e/ou exames. Estes instrumentos acabam tendo como finalidade apenas a verificação do nível de desempenho do educando em determinado conteúdo (entendendo conteúdo como o conteúdo programático ministrado numa disciplina, isto é, o conjunto de informações, conceitos, dados, habilidades mentais e motoras, etc.) e classificá-lo em termos de aprovação ou reprovação. Com isso, em vez de, de fato, avaliarem, provas ou exames acabam se constituindo numa prática seletiva que classifica e separa os estudantes "eleitos" dos "não eleitos".

$\mathrm{Na}$ Educação Infantil, a prática da avaliação classificatória[9] torna-se ainda mais nociva, na medida em que a clientela atendida por esta etapa é formada por seres humanos no início do seu processo de desenvolvimento. É por isso que os documentos estruturantes desta etapa da Educação no Brasil, como o "Referencial Curricular Nacional para a Educação Infantil" (RCNEI), de 1998, as "Diretrizes Curriculares Nacionais para a Educação Infantil" (DCNEI), de 2009, e, mais recentemente, a "Base Nacional Comum Curricular" (BNCC), de 2018, enfatizam a priorização da utilização de estratégias avaliativas diferenciadas, como a observação (individual e coletiva) e o registro (escrito, fotográfico e de imagens), como práticas norteadoras na Educação Infantil.

Para Oliveira (2002), a avaliação na Educação Infantil não é um espaço de julgamento, mas sim um campo de investigação. Para a autora, a avaliação na Educação Infantil "implica detectar mudanças em competências das crianças que possam ser atribuídas tanto ao trabalho na creche e pré-escola quanto à articulação dessas instituições com o cotidiano escolar" (OLIVEIRA, 2002, p. 255). 
Hoffmann (2012, p. 19), a este respeito, define alguns pressupostos básicos para a avaliação nesse nível de ensino:

a) uma proposta pedagógica que vise levar em conta a diversidade de interesse e possibilidades de exploração do mundo pela criança, respeitando sua própria identidade sociocultural e proporcionando-lhe um ambiente interativo, rico em materiais e situações experienciadas;

b) um professor curioso e investigador do mundo da criança, agindo como mediador de suas conquistas, no sentido de apoiá-la, acompanhála e favorecer-Ihe novos desafios;

c) um processo avaliativo permanente de observação, registro e reflexão acerca do pensamento das crianças, de suas diferenças culturais e de desenvolvimento, embasador do repensar do educador sobre o fazer pedagógico.

Dessa forma, no cotidiano do trabalho dos professores, diferentemente das etapas escolares subsequentes, a avaliação na Educação Infantil caracteriza-se por uma ênfase muito maior sobre o processo do que sobre o resultado. Independentemente da concepção pedagógica adotada pela unidade escolar e/ou pelo professor, a prática avaliativa nesta etapa é centrada na observação e no registro e na noção de progressão e de continuidade. Entre outros aspectos, os professores procuram observar e registrar a participação das crianças nas atividades; seu grau de autonomia; suas habilidades e dificuldades; seu comportamento nas aulas; a relação com colegas e professores; a reação a conquistas e fracassos e diante de conflitos e adversidades; e o grau de avanço.

Isso faz com que a noção de avaliação na Educação Infantil tenha assumido um caráter diferenciado e bem mais amplo em relação às práticas avaliativas nas etapas escolares subsequentes. Assim, enquanto na Educação Infantil assimilou-se, nas práticas predominantes, a perspectiva de diagnóstico, processo, progressão, ritmo, formação, inclusão e qualificação na avaliação, a partir dos Anos Iniciais do Ensino 
Fundamental[10], permanece o domínio das dimensões de resultado, quantificação, acumulação, seleção, exclusão, controle e punição.

Para além das particularidades da faixa etária atendida pela Educação Infantil, isto é, crianças de 0 a 5 anos, o caráter diferenciado da Educação Infantil pode ser explicado pelo fato desta etapa não ter sido contaminada pela chamada Pedagogia do Exame, que consiste na prática avaliativa baseada quase exclusivamente no resultado da aplicação de testes, utilizando uma escala matemática quantitativa e classificatória como forma de disciplinamento e controle social dos alunos. A crítica recai particularmente sobre o fato de que a prática da Pedagogia do Exame teria produzido uma cultura pedagógica e escolar que confunde avaliação com a aplicação de testes ou provas e que confunde resultado da avaliação com a atribuição de notas numa escala quantitativa, quase sempre de 0 a 10 ou de 0 a 100.

\subsection{DEFINIÇÕES DA AVALIAÇÃO NA EDUCAÇÃO INFANTIL}

A avaliação na Educação Infantil apresenta um caráter diferenciado, em função das particularidades da faixa etária deste nível de ensino (crianças de 0 a 5 anos), sendo predominantemente voltada para a observação e o registro. Face a este contexto, as professoras da Educação Infantil acabam lançando mão de uma diversidade muito maior de recursos e instrumentos avaliativos que os professores das demais etapas da Educação Básica. Na visão de Micarello (2010), isso se dá porque as referências para a realização dos processos de avaliação na Educação Infantil devem ser buscadas na própria criança e não em padrões pré-estabelecidos e de natureza externa, imposto pelos adultos, aos quais ela deve corresponder.

Nesta perspectiva, Hoffmann (2012, p. 13) entende que a avaliação na Educação Infantil constitui, na verdade, "um conjunto de procedimentos didáticos que se estendem por um longo tempo e em vários espaços escolares, de caráter processual e visando, sempre, a melhoria do objeto avaliado". Como a avaliação, nesta etapa até por determinação do Artigo 31, Inciso I, da LDB (Lei no 9.394/96), que estabelece que, na Educação Infantil, a avaliação será organizada "mediante acompanhamento e registro do desenvolvimento das crianças, sem o objetivo de promoção, mesmo para 
o acesso ao ensino fundamental" (BRASIL, 1996, Art. 31) -, não tem o objetivo de realizar promoção para 0 ano de escolaridade seguinte e, consequentemente, também não tem o objetivo de realizar a retenção na mesma série, não são utilizados na Educação Infantil a realização de testes ou provas ou de qualquer outro instrumento de natureza quantitativa, o que acaba abrindo espaço para o maior reconhecimento da diferenciação dos ritmos de aprendizagem das crianças e a priorização dos aspectos qualitativos da avaliação, como, por exemplo, a observação e o registro do estágio de desenvolvimento e dos avanços obtidos por cada criança.

Assim, Silva e Urt (2014) destacam que o trabalho na Educação Infantil se faz a partir de vários olhares, enquanto Faria e Besseler (2014, p. 161) enfatizam que "a avaliação na educação infantil é marcada por diversos âmbitos que demandam um olhar multifacetado e diferentes linguagens". Um ponto relevante levantado pelas quatro autoras é a importância do reconhecimento da construção mediada do conhecimento na Educação Infantil: a criança aprende sozinha, a partir da interação com o meio, com outras crianças e com um objeto da realidade, porém ela precisa da orientação da professora para construir de forma direcionada o conhecimento. Dessa forma, é possível dizer que o objetivo de não realização de promoção, ao mesmo tempo em que fecha o espaço para a Pedagogia do Exame, acaba abrindo espaço para a avaliação mediadora, que tem como característica, no entendimento de Hoffmann (2012), a observação individualizada da criança, a ação reflexiva sobre os diversos comportamentos do educando e o planejamento como forma intencional de proposição de atividades significativas.

Nessa perspectiva, segundo a mesma autora (HOFFMANN, 2012), a prática da avaliação mediadora coloca a participação do professor como fundamental, na medida em que é ele o observador, capaz de refletir e construir os saberes necessários para melhor conduzir a ação pedagógica.

Assim, os resultados da avaliação não devem ser interpretados apenas como um conceito final, mas como o ponto de partida para a revisão e alteração das condições de ensino, visando ao aprimoramento do processo de apropriação do conhecimento pelo aluno. Em outras palavras: "os resultados apresentados pela avaliação precisam 
ser entendidos como o ponto de partida para um novo planejamento, visando um trabalho que permita o crescimento e desenvolvimento daquele que foi avaliado" (FARIA; BESSELER, 2014, p. 168).

Por isso, conclui-se que a avaliação deve servir a todos os atores da escola, pois

a avaliação deve ser um processo contínuo e de caráter formativo, que deve partir do professor, orientado pela equipe gestora da instituição, e contemplar aspectos que the permitam conhecer profundamente seus alunos e a si mesmo, contribuindo para a revisão de suas práticas pedagógicas e, consequentemente, para a melhoria da qualidade de ensino no âmbito da Educação Infantil (FARIA; BESSELER, 2014, p. 164).

Assim, especialmente no caso da Educação Infantil, é possível afirmar que a visão da avaliação escolar sob a perspectiva diagnóstica, processual e qualitativa, ao contrário da visão de avaliação predominante nas demais etapas da Educação Básica, associada à Pedagogia do Exame, tem a finalidade de garantir a efetivição dos direitos de aprendizagem e de desenvolvimento das crianças e, assim, promover a educação integral e saudável dos pequenos.

A exemplo do que acontece na rede municipal de educação da cidade capixaba de Presidente Kennedy, conforme se verá a seguir, muitas escolas e redes de ensino do Brasil, públicas e particulares, ainda não adotam, na Educação Infantil, uma prática avaliativa em acordo com a proposta defendida pela BNCC.

\subsection{A AVALIAÇÃO NA EDUCAÇÃO INFANTIL NO MUNICÍPIO DE PRESIDENTE KENNEDY}

A avaliação da etapa da Educação Infantil na Rede Municipal de Presidente Kennedy apresenta duas dimensões: a primeira é aquela que se pode chamar de "avaliação interna", fruto do acompanhamento da professora regente da própria turma, enquanto a segunda é aquela que se pode chamar de "avaliação externa", realizada pela equipe 
pedagógica da SEME. Em ambos os casos, os instrumentos de avaliação utilizados são compostos por observação e registro.

No caso da avaliação interna, tomando como ponto de partida um conjunto qualitativo de critérios selecionados, divididos nos cinco campos de experiências da BNCC (os cinco campos são: o eu, o outro e o nós; escuta, fala, pensamento e imaginação; espaços, tempos, quantidades, relações e transformações; traços, sons, cores e imagens; e corpo, gestos e movimentos), as professoras regentes[11] observam, avaliam e registram na ficha avaliativa o nível de avanço do desenvolvimento dos alunos com base em três situações: "alcançado", "em desenvolvimento" e "conteúdo não trabalhado". Por "alcançado", as professoras entendem[12] o desenvolvimento satisfatório de uma dada habilidade, competência ou capacidade de realização de uma dada tarefa, enquanto que por "em desenvolvimento" as professoras compreendem o desenvolvimento ou a capacidade insatisfatória da mesma habilidade, competência ou realização de tarefa.

Entre os critérios selecionados em "o eu, o outro e o nós", estão a demonstração de autoestima e autoconfiança, o reconhecimentos das próprias limitações, o uso do diálogo como ferramenta para a resolução de conflitos, a expressão de atitudes de cooperação, respeito e solidariedade e o conhecimento do próprio corpo e das próprias habilidades físicas.

Entre os critérios em "escuta, fala, pensamento e imaginação", estão a expressão oral, a participação em conversas, o uso de formas de expressões não faladas, a identificação de letras, números e sons e o reconhecimento do próprio nome escrito.

Em "espaços, tempos, quantidades, relações e transformações" são avaliados a capacidade de organização, comparação, classificação, ordenamento, resolução de situações-problema e de estabelecimento de relações espaciais de vizinhança (perto/longe/próximo), de posição (abaixo/acima/entre/ao lado/à direita/à esquerda) e de direção de sentido (para frente/para trás/para direita/para a esquerda/para cima/para baixo/no mesmo sentido/em sentido diferente). 
Em "traços, sons, cores e imagens" são avaliados a produção e a apreciação artística, a percepção musical e a coordenação motora, enquanto em "corpo, gestos e movimentos", são observados o equilíbrio, ritmo, força, velocidade, resistência e flexibilidade corporal, a coordenação dos movimentos e o uso da imaginação em atividades livres e dirigidas.

Por sua vez, a avaliação externa, realizada pela equipe pedagógica da SEME, busca acompanhar a evolução da aprendizagem dos alunos de toda a Educação Infantil, também por meio da observação e do registro em ficha avaliativa. No caso da Préescola, particularmente das turmas de Pré II das EMEIEFs, compostas por alunos de 5 anos, há uma preocupação maior com a verificação do avanço em relação ao processo de alfabetização, a fim de constatar as condições pedagógicas nas quais estes estudantes vão iniciar os estudos no $1^{\circ}$ ano do Ensino Fundamental, a partir do ano escolar seguinte.

Utilizando como referência a metodologia proposta por Ferreiro e Teberosky (1984)[13], que classifica a evolução do processo de alfabetização em pré-silábica, silábica, silábico-alfabética e alfabética, a equipe pedagógica da SEME também aplica um ditado aos alunos das turmas de Pré II, a fim de identificar o avanço dos estudantes de 5 anos em relação à capacidade de decodificação (reconhecimento de letras), formação de sílabas e palavras e de leitura e escrita.

\section{METODOLOGIA}

\subsection{A PESQUISA}

Com a finalidade de responder à questão-problema da pesquisa que gerou este artigo - qual a compreensão das professoras de Educação Infantil, particularmente as da Pré-escola, da Rede Municipal de Presidente Kennedy-ES sobre a avaliação nesta etapa da Educação Básica? - e de atender aos objetivos geral e específicos propostos, utilizou-se uma metodologia baseada num estudo de caso exploratório com abordagem qualitativa da percepção e prática da avaliação escolar das professoras da Pré-escola da Educação Infantil da Rede Municipal de Presidente Kennedy. 
Para efeitos operacionais, o universo foi coberto por meio de observações in loco das escolas e grupo focal com as 12 professoras regentes de três EMEIEFs que oferecem esta etapa educacional. Ao todo, as 12 professoras regentes acompanham um total de mais de 200 crianças.

No decorrer da aplicação da metodologia também foram observadas as fichas de registro (as escolas da rede municipal capixaba trabalham com fichas de avaliação específicas para cada ano de escolarização) com o intuito de compreender qual a estratégia avaliativa desenvolvida por cada unidade escolar, apoiada no princípio da autonomia pedagógica.

\subsection{PROCEDIMENTOS METODOLÓGICOS}

Para atender a pretensão de realização de um estudo de caso exploratório com abordagem qualitativa foram realizadas observações das escolas e grupo focal com 12 professoras regentes de turmas da Pré-escola da Educação Infantil da Rede Municipal de Presidente Kennedy, a fim de captar a percepção destas professoras sobre o que é avaliar e sobre o como avaliar, bem como compreender como se dá a prática de avaliação escolar destas professoras.

Para tanto, foi realizado um grupo focal com as professoras, num roteiro semiestruturado com 9 perguntas, a fim de captar desde a compreensão dos instrumentos avaliativos e a busca de informações sobre a prática avaliativa destas professoras até a opinião das mesmas sobre os instrumentos avaliativos confeccionados pela escola e pela SEME.

Em termos de cronograma, o grupo focal, assim como as observações de campo, foram realizadas na terceira semana de março de 2020.

\subsection{O LÓCUS DA PESQUISA}

O lócus da pesquisa é o município de Presidente Kennedy, localizado no litoral sul do estado do Espírito Santo, em um território de 583,932 km², e com população estimada, 
em 01 de julho de 2019, pelo Instituto Brasileiro de Geografia e Estatística (IBGE), em 11.574 habitantes (IBGE, 2019).

Banhado a sudeste pelo Oceano Atlântico, Presidente Kennedy faz divisa, a sul, com o estado do Rio de Janeiro e com os municípios fluminenses de Campos dos Goytacazes e São Francisco do Itabapoana, a oeste com o município capixaba de Mimoso do Sul, a noroeste com Atílio Vivácqua, a norte com Itapemirim e a oeste com Marataízes, concentrando sua área urbanizada, basicamente, em torno de sua sede municipal e de algumas localidades com função de balneário de veraneio, como se pode observar no mapa a seguir, produzido pela base de dados geoespaciais do estado do Espírito Santo:

Figura 1 - Mapa do município de Presidente Kennedy.

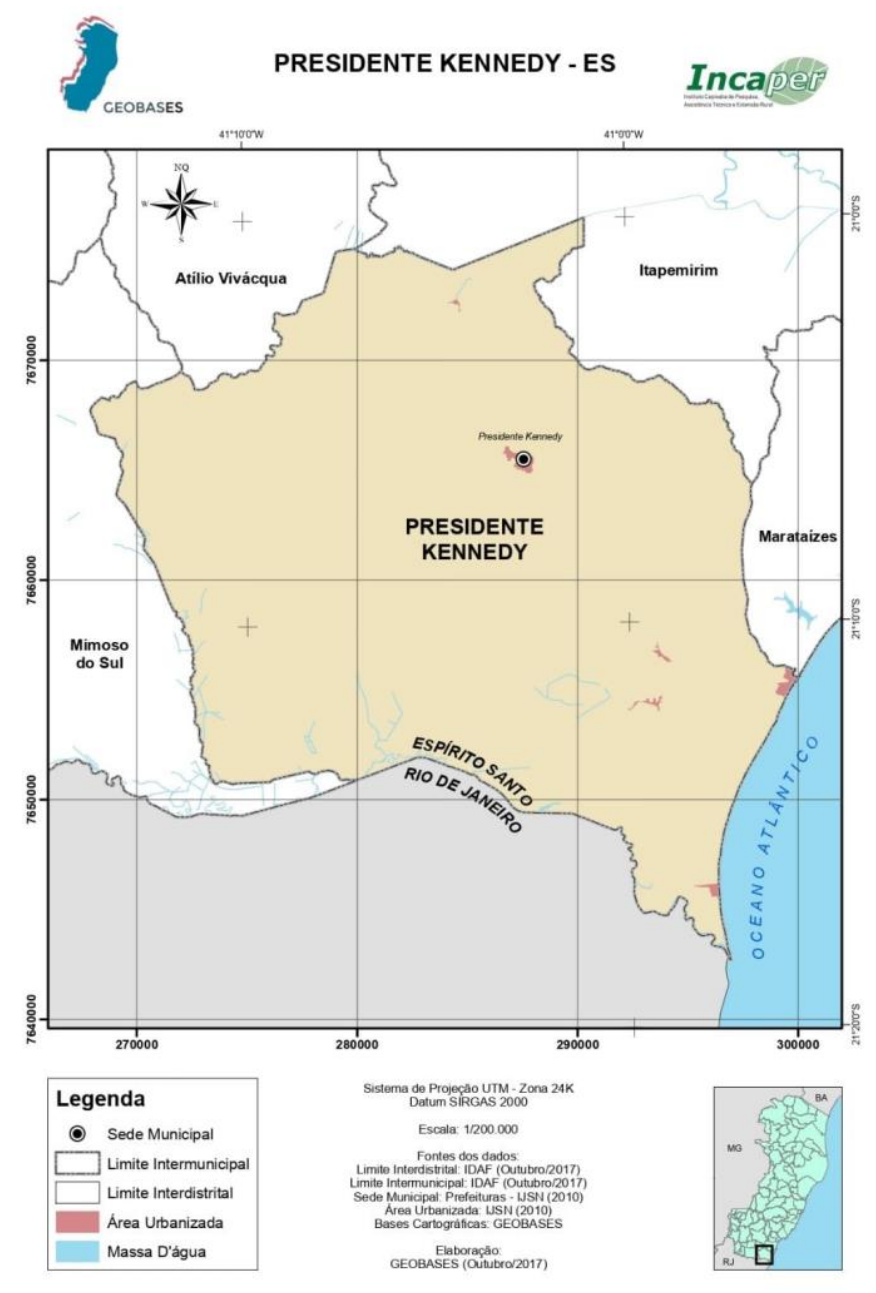


Fonte: GEOBASES - Base de Dados Geoespaciais do Governo do Estado do Espírito Santo. Disponível em: <https://geobases.es.gov.br/mapas-munic\%C3\%ADpios-es>. Acesso em: 26 out. 2019.

De acordo com a página na internet da própria prefeitura, Presidente Kennedy possui economia majoritariamente voltada para a agropecuária, com destaque para o cultivo de mandioca, maracujá, cana-de-açúcar, mamão e, de modo especial, a produção de leite, atividade na qual o município é o maior produtor estadual (PRESIDENTE KENNEDY, 2019).

De acordo com o Índice de Desenvolvimento da Educação Básica (Ideb), do Instituto Nacional de Estudos e Pesquisas Educacionais Anísio Teixeira (INEP), Presidente Kennedy apresentou Ideb de 5,9 na última avaliação, realizada em 2017, dos Anos Iniciais do Ensino Fundamental oferecidos pelas escolas municipais (INEP, 2017). A nota representa uma queda significativa em relação a 2015, quando o município atingiu 6,4 e despontava como referência de melhoria de qualidade da educação no Espírito Santo (INEP, 2015).

No total, de acordo com o Censo Escolar 2018 (INEP, 2018), o município possui 22 escolas, sendo apenas uma privada, totalizando 3.568 alunos matriculados. Os estudantes matriculados em pré-escolas no município somam 408 , sendo que todas estas unidades pertencem a rede municipal.

\subsection{SUJEITOS DA PESQUISA}

Os sujeitos da pesquisa, portanto, são as professoras regentes das turmas da Préescola (Pré I e Pré II) da Educação Infantil da Rede Municipal de Presidente Kennedy. Como se pode ver no Quadro 1, a seguir, as turmas de Pré 1 e Pré 2, considerando o que determina a LDB (Lei o 9.394/96), devem atender somente a alunos, respectivamente, de 4 e 5 anos, desde que tenham completado aniversário a partir da data de 31 de março do ano letivo corrente. 
Quadro 1 - Ano de escolarização na Educação Infantil de acordo com a idade das crianças, considerando o aniversário a partir de 31 de março.

\begin{tabular}{|l|l|l|}
\hline Ano de escolarização & Idade & Etapa \\
\hline Berçário I & A partir de 3 meses & Creche \\
\hline Berçário II & 1 ano & Creche \\
\hline Maternal I & 2 anos & Creche \\
\hline Maternal II & 3 anos & Creche \\
\hline Pré-Escola I ou Jardim & 4 anos & Pré-Escola \\
\hline Pré-Escola II & 5 anos & Pré-Escola \\
\hline
\end{tabular}

Fonte: Elaboração própria.

A escolha de três EMEIEFs da Rede Municipal de Presidente Kennedy que oferecem turmas de Pré-escola, por sua vez, se deu pela compreensão de que este número corresponde a uma amostra de toda rede.

Para preservar a identidade das unidades escolares, as três EMEIEFs serão representadas, a seguir, pelas letras PK, iniciais de Presidente Kennedy, sucedidas pelos números 1, 2 e 3 . Além da Pré-Escola, as unidades oferecem Anos Iniciais ( $1^{\circ}$ ao 5 ano) e Anos Finais do Ensino Fundamental (6ํㅜ ao 9ํㅜ), Educação de Jovens e Adultos (Ensino Fundamental) e Educação Especial.

A primeira unidade escolhida, a PK1, está localizada em área urbana. De acordo com o Censo Escolar (INEP, 2018), a EMEIEF possui, aproximadamente, 100 funcionários, tendo registrado, em 2018, último dado disponível, mais de 600 alunos matriculados (INEP, 2018). Em 2017, apresentou Ideb de 6,0 nos Anos Iniciais do Ensino Fundamental, superando em 0,8 a meta de 5,2 para a escola estabelecida pelo Ministério da Educação (INEP, 2017).

No que diz respeito a turno, número de matrículas e de professoras regente, as turmas da Pré-escola da EMEIEF PK1 estão distribuídas conforme o Quadro 2: 
Quadro 2 - Turmas da EMEIEF PK1.

\begin{tabular}{|c|c|c|c|}
\hline Turmas & Turno & Alunos & $\begin{array}{l}\text { Número de } \\
\text { Professoras }\end{array}$ \\
\hline Pré I M 1 & Matutino & 14 alunos & $\begin{array}{l}1^{\text {a }} \\
\text { Regente }\end{array}$ \\
\hline Pré I M 2 & Matutino & 13 alunos & $\begin{array}{l}1^{\text {a }} \\
\text { Regente }\end{array}$ \\
\hline Pré II M 1 & Matutino & 19 alunos & $\begin{array}{l}1^{\underline{a}} \\
\text { Regente }\end{array}$ \\
\hline Pré II M 2 & Matutino & 19 alunos & $\begin{array}{l}1^{\text {a }} \\
\text { Regente }\end{array}$ \\
\hline Pré I V 1 & Vespertino & 17 alunos & $\begin{array}{l}1^{\text {a }} \quad \text { Prof. } \\
\text { Regente }\end{array}$ \\
\hline Pré I V 2 & Vespertino & 14 alunos & $\begin{array}{l}1^{\text {a }} \\
\text { Regente }\end{array}$ \\
\hline Pré II V 1 & Vespertino & 26 alunos & $\begin{array}{l}1^{\text {a }} \\
\text { Regente }\end{array}$ \\
\hline
\end{tabular}

Fonte: Elaboração própria.

As demais unidades escolhidas situam-se no interior do município, em área rural. A segunda EMEIEF, PK2, possui mais de 60 funcionários (INEP, 2018). Em 2018, tinha quase 500 alunos matriculados (INEP, 2018) e, em 2017, apresentou Ideb de 5,7 nos Anos Iniciais do Ensino Fundamental, superando a meta estabelecida em 5,0 (INEP, 2017).

Quanto a organização, as turmas da Pré-escola da EMEIEF PK2 estão distribuídas conforme o Quadro 3: 
Quadro 3 - Turmas da EMEIEF PK2.

\begin{tabular}{|l|l|l|l|}
\hline Turmas & Turno & Alunos & Número de \\
\hline Pré I & Vespertino & 18 alunos & $1^{\underline{a}} \quad$ Prof. $\underline{a}$ \\
\hline Pré II & Vespertino & 20 alunos & $1^{\underline{a}} \quad$ Prof. $\underline{\text { Regente }}$ \\
& & & Regente \\
\hline
\end{tabular}

Fonte: Elaboração própria.

A terceira EMEIEF, PK3, possui mais de 100 funcionários (INEP, 2018), registrou quase 800 alunos matriculados (INEP, 2018) em 2018 e Ideb de 5,8 nos Anos Iniciais do Ensino Fundamental, em 2017 - a meta estabelecida era de 4,6 (INEP, 2017).

Quanto a organização, as turmas da Pré-escola da EMEIEF PK3 estão distribuídas conforme o Quadro 4:

Quadro 4 - Turmas da EMEIEF PK3.

\begin{tabular}{|c|c|c|c|}
\hline Turmas & Turno & Alunos & $\begin{array}{l}\text { Número de } \\
\text { Professoras }\end{array}$ \\
\hline Pré I & Matutino & 15 alunos & $\begin{array}{l}1^{\mathrm{a}} \quad \text { Prof. } \\
\text { Regente }\end{array}$ \\
\hline Pré I & Vespertino & 20 alunos & $\begin{array}{ll}1^{\mathrm{a}} & \text { Prof. } \\
\text { Regente }\end{array}$ \\
\hline Pré II & Vespertino & 21 alunos & $\begin{array}{l}1^{\mathrm{a}} \quad \text { Prof. } \\
\text { Regente }\end{array}$ \\
\hline
\end{tabular}

Fonte: Elaboração própria.

Portanto, considerando que as três EMEIEFs detêm, no total, 12 professoras regentes nas turmas de Pré-escola e considerando que são essas professoras regentes 0 
universo selecionado para o grupo focal, estas 12 professoras, então, serão o sujeito da pesquisa desta dissertação.

\section{RESULTADOS DA PESQUISA}

\subsection{RESULTADOS DO GRUPO FOCAL}

Seguindo um roteiro semiestruturado com 9 perguntas, realizou-se um grupo focal com as professoras regentes da Pré-escola de três EMEIEFs da Rede Municipal de Educação de Presidente Kennedy.

Na primeira EMEIEF, isto é, a PK1, foi realizado grupo focal com 7 professoras: 4 do turno matutino e 3 do turno vespertino. Na EMEIEF PK2, foram entrevistadas as duas professoras do vespertino, enquanto na EMEIEF PK3 o número de entrevistadas foi 3: uma do matutino e duas do vespertino.

A fim de garantir que todas as perguntas fossem respondidas e todas as respostas validadas, repetiu-se as perguntas do roteiro em alguns casos, mudando apenas a forma de sua realização. Para preservar as identidades das entrevistadas, os nomes das professoras foram substituídos pelo nome fictício das EMEIEFs utilizados aqui seguido por uma letra minúscula associada a ordem das professoras que responderam às perguntas. Assim, a primeira professora da EMEIEF PK1 que falou durante o grupo focal recebeu a nomeação PK1a, enquanto a terceira professora da EMEIEF PK3, a última a responder o grupo focal, recebeu a nomeação PK3c.

Com o objetivo de conhecer o nível de formação e o tempo de atuação na Educação Infantil das professoras regentes, o grupo focal começou realizando a pergunta número 1: "Qual a sua formação? E há quanto tempo você atua na Educação Infantil?". Os resultados das respostas estão apresentados no Quadro 5 a seguir. 
Quadro 5 - Formação e tempo de atuação na Educação Infantil das professoras entrevistadas.

\begin{tabular}{|c|c|c|c|c|c|}
\hline $\begin{array}{l}\text { Professor } \\
\text { a }\end{array}$ & 1ª Graduação & $\begin{array}{l}2^{\underline{a}} \\
\text { Graduaçã } \\
0\end{array}$ & $\begin{array}{l}1^{\text {a }} \quad \text { Pós- } \\
\text { Graduação }\end{array}$ & $\begin{array}{l}2^{a} \quad \text { Pós- } \\
\text { Graduação }\end{array}$ & $\begin{array}{l}\text { Tempo } \\
\text { de } \\
\text { atuaçã } \\
\text { o na El }\end{array}$ \\
\hline PK1a & Matemática & Pedagogia & Não possui & Não possui & 5 anos \\
\hline PK1b & Pedagogia & $\begin{array}{l}\text { Não } \\
\text { possui }\end{array}$ & $\begin{array}{l}\text { Alfabetizaçã } \\
0 \\
\text { Letramento }\end{array}$ & $\begin{array}{l}\text { Educação } \\
\text { Inclusiva }\end{array}$ & 2 anos \\
\hline PK1c & Pedagogia & $\begin{array}{l}\text { Não } \\
\text { possui }\end{array}$ & $\begin{array}{l}\text { Educação } \\
\text { Infantil }\end{array}$ & $\begin{array}{l}\text { Inclusão e } \\
\text { Educação } \\
\text { Especial }\end{array}$ & $\begin{array}{l}3 \\
\text { meses }\end{array}$ \\
\hline PK1d & Pedagogia & Geografia & Artes & $\begin{array}{l}\text { Alfabetizaçã } \\
\text { o e } \\
\text { Letramento }\end{array}$ & 6 anos \\
\hline PK1e & Pedagogia & $\begin{array}{l}\text { Não } \\
\text { possui }\end{array}$ & $\begin{array}{l}\text { Educação } \\
\text { Infantil }\end{array}$ & Não possui & 31 anos \\
\hline PK1f & Pedagogia & $\begin{array}{l}\text { Não } \\
\text { possui }\end{array}$ & $\begin{array}{l}\text { Alfabetizaçã } \\
0 \\
\text { Letramento }\end{array}$ & Não possui & 1 mês \\
\hline PK1g & Pedagogia & $\begin{array}{l}\text { Não } \\
\text { possui }\end{array}$ & $\begin{array}{l}\text { Educação } \\
\text { Infantil }\end{array}$ & Não possui & $\begin{array}{l}5 \\
\text { meses }\end{array}$ \\
\hline PK2a & $\begin{array}{l}\text { Letras/Literatur } \\
\text { a }\end{array}$ & $\begin{array}{l}\text { Não } \\
\text { possui }\end{array}$ & $\begin{array}{l}\text { Gestão } \\
\text { Escolar }\end{array}$ & Pedagogia & 3 anos \\
\hline PK2b & Pedagogia & $\begin{array}{l}\text { Não } \\
\text { possui }\end{array}$ & $\begin{array}{l}\text { Alfabetizaçã } \\
0 \\
\text { Letramento }\end{array}$ & Não possui & 10 anos \\
\hline PK3a & Pedagogia & $\begin{array}{l}\text { Não } \\
\text { possui }\end{array}$ & Não possui & Não possui & 3 anos \\
\hline
\end{tabular}




\begin{tabular}{|l|l|l|l|l|l|}
\hline PK3b & Letras/Literatur & $\begin{array}{l}\text { Não } \\
\text { possui }\end{array}$ & $\begin{array}{l}\text { Alfabetizaçã } \\
0\end{array}$ & Não possui & 5 anos \\
Petramento & e & & \\
\hline PK3c & Pedagogia & $\begin{array}{l}\text { Não } \\
\text { possui }\end{array}$ & $\begin{array}{l}\text { Educação } \\
\text { Infantil }\end{array}$ & Não possui & 4 anos \\
\hline
\end{tabular}

Fonte: Elaboração da autora a partir dos resultados do grupo focal.

Para melhor compreensão, os resultados das respostas foram convertidos em valores percentuais. O gráfico 1, a seguir, apresenta o percentual de formação em nível de pós-graduação das professoras regentes da Pré-escola das três EMEIEFs da Rede Municipal de Presidente Kennedy.

Gráfico 1 - Formação das professoras.

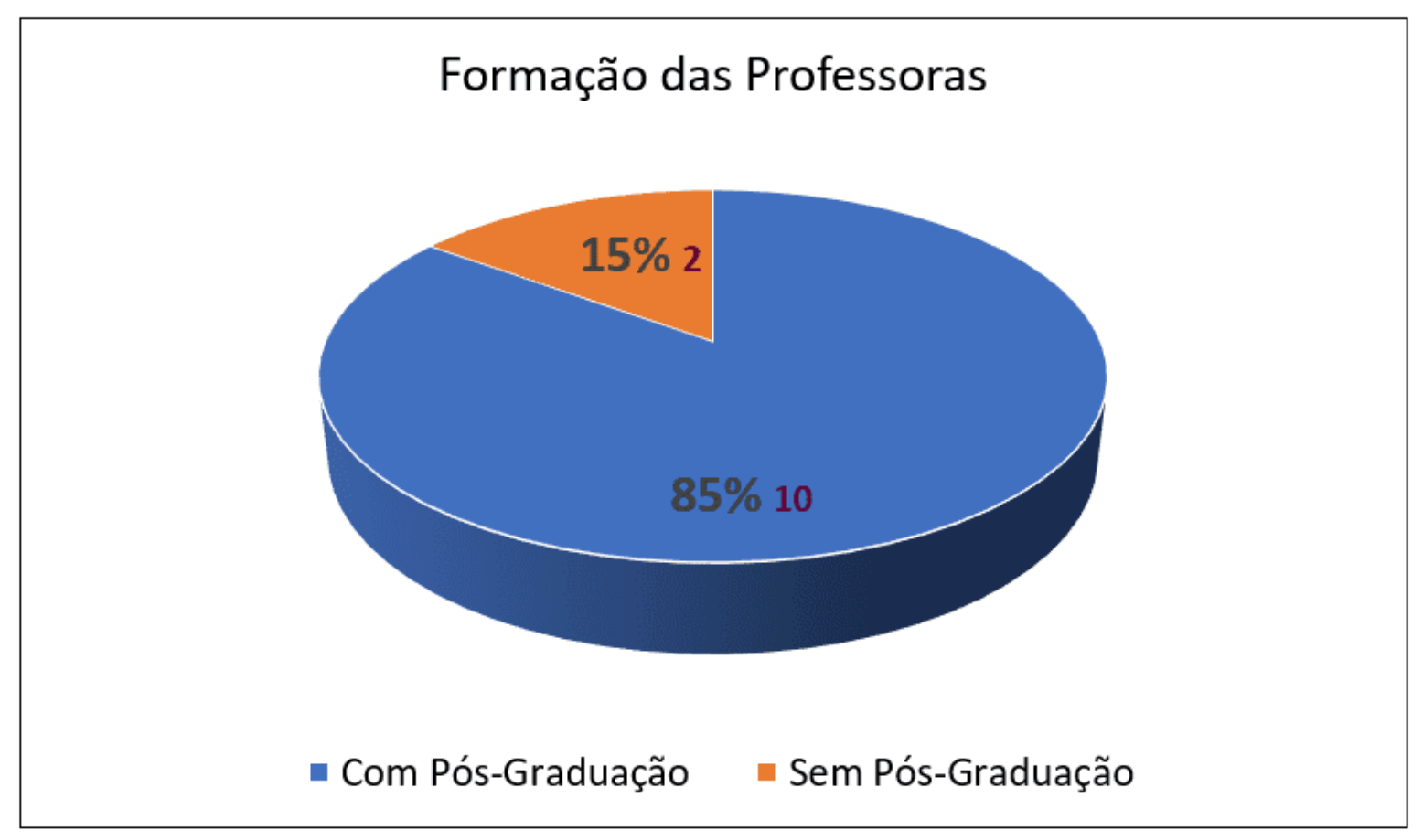

Fonte: Elaboração da autora a partir dos resultados do grupo focal.

Como se pode observar, $85 \%$ (10 professoras) das professoras regentes da Préescola das três EMEIEFs da Rede Municipal de Presidente Kennedy possuem pósgraduação, enquanto 15\% das professoras são somente graduadas. Como o objetivo 
do grupo focal foi o de captar a percepção das professoras a respeito do que é a avaliação escolar, não se investigou o que levou $85 \%$ das professoras a cursarem uma pós-graduação nem o que levou 15\% (2 professoras) dessas docentes a não alcançarem esse nível de qualificação. No entanto, é possível que o incentivo proporcionado pelo programa municipal de bolsas de estudos de Presidente Kennedy, direcionado para moradores com mais de 10 anos de residência, tenha colaborado para que a maioria das professoras abordadas tenha alcançado o grau de escolaridade mencionado[14].

A fim de ampliar a compreensão sobre a formação em nível de pós-graduação de 85\% dessas professoras, o gráfico 2 detalha, percentualmente, as especializações. Considerando que 4 professoras, ou 33\% do total, apresentam uma segunda pósgraduação, como é de se imaginar, a soma das especializações ultrapassa 100\%.

Gráfico 2 - Especialização das Pós-graduações das professoras.

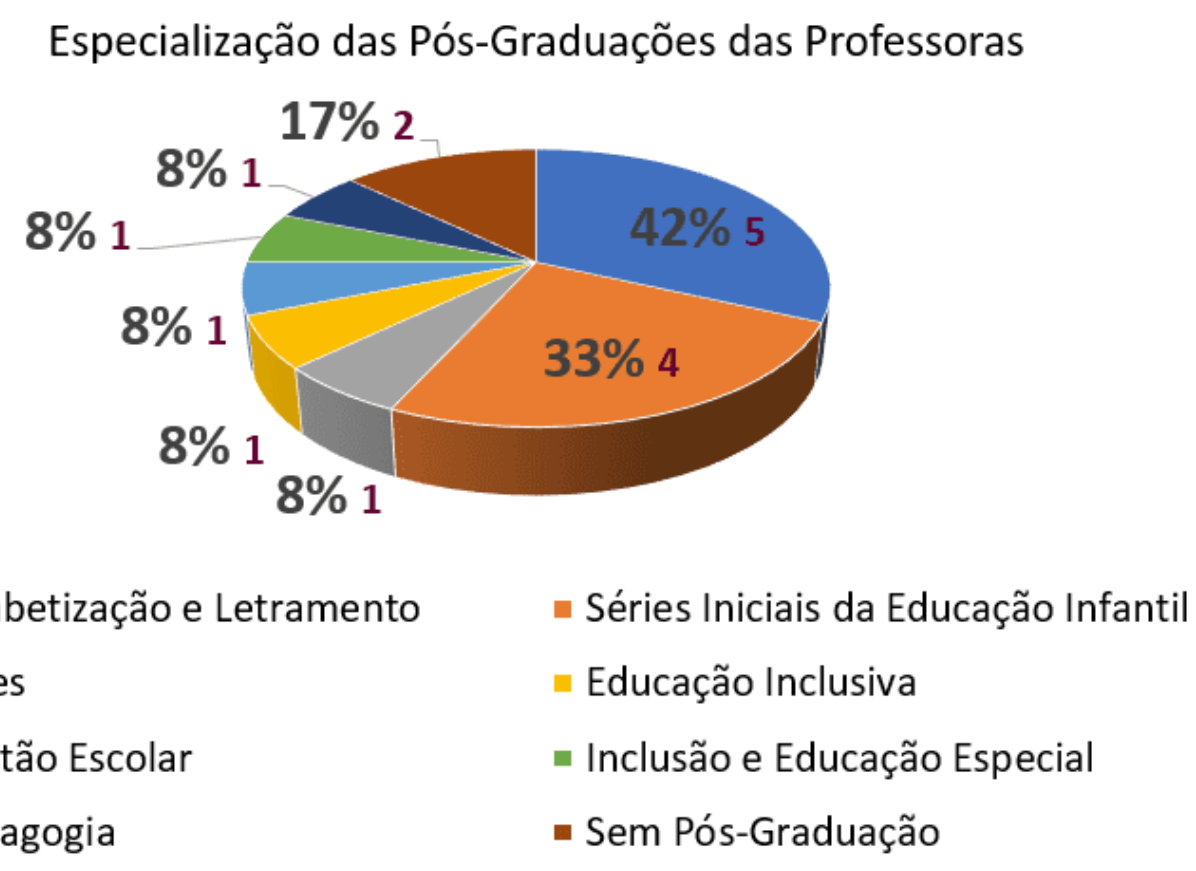

Fonte: Elaboração da autora a partir dos resultados do grupo focal.

De acordo com o gráfico 2, do total de professoras pós-graduadas, $42 \%$ ( 5 docentes) das professoras são pós-graduadas em Alfabetização e Letramento, 33\% (4 docentes) 
são pós-graduadas em Séries Iniciais da Educação Infantil, 8\% (1 docente) são pósgraduadas em Artes, 8\% (1 docente) em Gestão Escolar, 8\% (1 docente) em Educação Inclusiva, 8\% (1 docente) em Inclusão e Educação Especial e 17\% (2 docentes) não possuem pós-graduação.

Quanto a graduação, todas as 12 professoras (ou 100\%) possuem formação em nível superior, sendo que duas (16\%) também possuem uma segunda licenciatura. Para ampliar a compreensão, o gráfico 3 detalha, percentualmente, as especializações. Considerando que $16 \%$ das professoras possuem uma segunda graduação, a soma das especializações também ultrapassa $100 \%$.

Gráfico 3 - Especialização das Graduações das professoras.

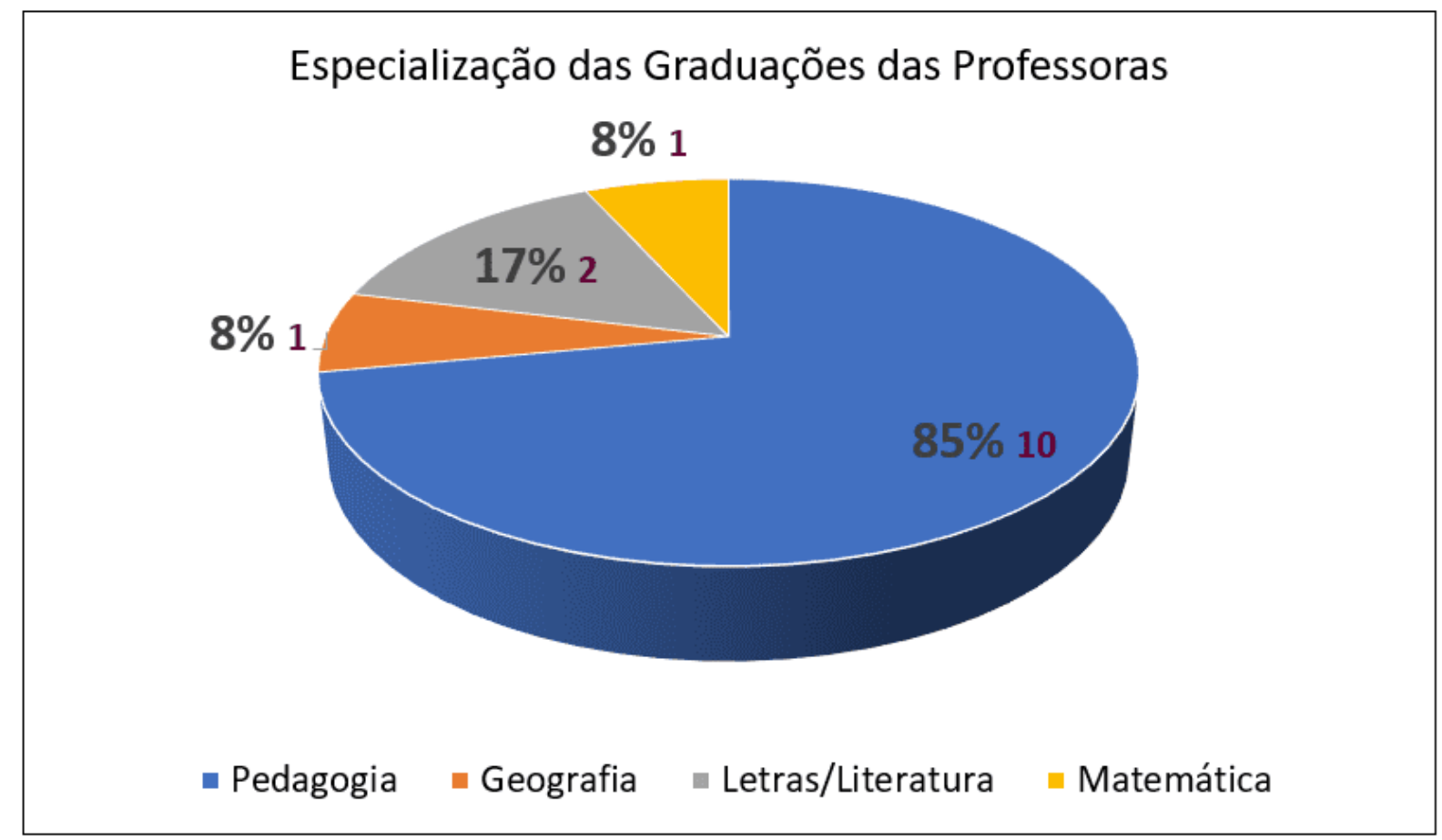

Fonte: Elaboração da autora a partir dos resultados do grupo focal.

Como é possível observar, das 12 professoras abordadas, 10 (85\%) são formadas em Pedagogia, enquanto duas (17\%) são licenciadas em Letras/Literatura, uma é licenciada em Geografia (8\%) e uma, licenciada em Matemática (8\%). 
Por outro lado, quanto ao tempo de atuação destas professoras na Educação Infantil, os resultados mostram que o tempo médio de atuação das professoras da EMEIEF PK1 neste segmento é de 7 anos e 5 meses[15]. O tempo médio das professoras da EMEIEF PK2 é de 6 anos e 6 meses e o tempo médio das docentes da EMEIEF PK3 é de 4 anos. No conjunto das EMEIEFs selecionadas, o tempo médio de atuação na Educação Infantil das professoras é de 6 anos e 5 meses. Portanto, na média, a EMEIEF PK1 é a que tem um corpo docente com mais anos de experiência, enquanto a EMEIEF PK3 é a que tem o corpo docente menos veterano. A EMEIEF PK1 é ainda a escola que abriga a professora com maior experiência (PK1e, 31 anos) e, ao mesmo tempo, também aquela com menos tempo de Educação Infantil (PK1f, apenas 1 mês).

A segunda pergunta direcionada ao grupo focal, "Você tem quantos alunos na sua turma?", procurou confirmar o total de alunos acompanhado por cada professora regente. Os resultados das respostas encontram-se discriminados no Quadro 6 a seguir.

Quadro 6 - Total de alunos da Educação Infantil acompanhado por cada professora abordada.

\begin{tabular}{|l|l|l|l|l|}
\hline Professora & EMEIF & Turma & Turno & Total de alunos \\
\hline PK1a & PK1 & Pré I & Matutino & 15 alunos \\
\hline PK1b & PK1 & Pré I & Matutino & 13 alunos \\
\hline PK1c & PK1 & Pré II & Matutino & 19 alunos \\
\hline PK1d & PK1 & Pré II & Matutino & 21 alunos \\
\hline PK1e & PK1 & Pré II & Vespertino & 19 alunos \\
\hline PK1f & PK1 & Pré I & Vespertino & 17 alunos \\
\hline PK1g & PK1 & Pré I & Vespertino & 14 alunos \\
\hline PK2a & PK2 & Pré I & Vespertino & 12 alunos \\
\hline PK2b & Pk2 & Pré II & Vespertino & 15 alunos \\
\hline PK3a & PK3 & Pré I & Matutino & 15 alunos \\
\hline PK3b & PK3 & Pré I & Vespertino & 20 alunos \\
\hline PK3c & PK3 & Pré II & Vespertino & 21 alunos \\
\hline
\end{tabular}


Fonte: Elaboração própria a partir dos resultados do grupo focal.

Em média, as professoras da EMEIEF PK1 têm 17 alunos por turma, enquanto as professoras da EMEIEF PK2 e da EMEIEF PK3 têm, respectivamente, 14 alunos e 19 alunos por classe. Em todos os casos, número dentro do limite de alunos permitido. Este dado foi incluído na pesquisa porque a quantidade de alunos por turma constitui um importante elemento de qualidade para o trabalho das professoras, na medida em que, quanto maior a proporção de alunos, maior o cansaço das docentes.

Dando prosseguimento a investigação do grupo focal, foi realizada a pergunta número 3 "O que você compreende por instrumentos avaliativos?". No conjunto das respostas, percebeu-se uma visão de processo e de totalidade por parte de algumas professoras, que consideraram que a avaliação deve envolver todos os momentos da vivência escolar dos alunos, dando especial atenção para os avanços nessa trajetória. Outro elemento a ser destacado é o fato de que a palavra "observação" foi a que apareceu com maior frequência nas falas das professoras. A este respeito, destaca-se, na EMEIEF PK1, a fala das professoras PK1c, PK1e, PK1f e PK1g: "[Instrumento avaliativo] é a observação das atitudes e das ações da criança, dia após dia, progressivamente" (PROFESSORA PK1c, 2020); "[Instrumento avaliativo] é como se avalia o aluno no seu dia a dia, como ele se comporta. Eu avalio o meu aluno a todo momento, desde a hora que ele chega na escola até a hora que ele vai para casa" (PROFESSORA PK1e, 2020); "[...] o dia a dia da criança, a observação em sala de aula e até o que ele vem comentar com a gente" (PROFESSORA PK1f, 2020); "[São] maneiras diversas de avaliar o aluno. Eu avalio todos os dias, mas o município também tem a forma de avaliar o aluno" (PROFESSORA PK1g, 2020).

Na EMEIEF PK2, destaca-se a fala da Professora PK2a: "são os modos e estratégias que a gente usa para avaliar" (PROFESSORA PK2a, 2020).

Na EMEIEF PK3, merece destaque a compreensão da Professora PK3c: "É o todo. Em todo o tempo você está observando, avaliando o seu aluno" (PROFESSORA PK3c, 2020). 
Em seguida, lançou-se a pergunta número 4: "você utiliza algum tipo de instrumento avaliativo na sua rotina pedagógica? Qual ou quais e por quê?” De diferentes maneiras, todas as professoras mencionaram o uso da observação e do registro individual que o docente faz de cada aluno. Em alguns casos, foi apontada também a avaliação trimestral da SEME.

A este respeito, as falas principais na EMEIEF PK1 foram as seguintes: "síntese avaliativa semanal, baseada nos conteúdos que foram aplicados" (PROFESSORA PK1a, 2020); "avaliação através de relatório individual e, a cada trimestre, a avaliação da Secretaria de Educação" (PROFESSORA PK1b, 2020); "relatório individual e da Secretaria de Educação, além da amostra de escrita [avaliação diagnóstica sobre o nível de desenvolvimento da escrita dos alunos]" (PROFESSORA PK1e, 2020).

Também merece destaque, porém, a fala da Professora PK1d:

É desde a hora que a criança chega, através da observação. Na Educação Infantil a gente observa como a criança se comporta, como ela convive com o coleguinha, como ela vai desenvolver uma atividade que a gente vai fazer, vai dirigir as brincadeiras, o modo de conversar, o modo de respeitar. Então, a gente utiliza o tempo essa observação. Primeiro é a observação, aí a gente vai registrando para não esquecer. E por que a gente faz isso? Porque é importante. A gente precisa avaliar para a gente saber o que ele precisa melhorar, o que precisa mudar, o que a gente precisa trabalhar naquele aluno (PROFESSORA PK1d, 2020).

$\mathrm{Na}$ EMEIEF PK2, merece destaque a fala das professoras PK2a e PK2b: "são os modos e estratégias que a gente usa para avaliar" (PROFESSORA PK2a, 2020); "eu utilizo as fichas avaliativas e anoto as minhas observações do aluno" (PROFESSORA PK2b, 2020).

Contudo, destaque maior deve ser dado à Professora PK2c: 
Eu avalio a criança em si como um todo, o comportamento, se ela está codificando a proposta de atividade e a ficha avaliativa, a ficha descritiva porque ao final de todos os três períodos nós temos que fazer um relatório deles, uma avaliação escrita deles. Mas o tempo todo em sala de aula, todos os dias, até mesmo com o lúdico a gente está avaliando (PROFESSORA PK2c, 2020).

$\mathrm{Na}$ EMEIEF PK3, por sua vez, selecionou-se o que foi dito pelas professoras PK3b e PK3c: "na Educação Infantil, pelo que eu conheça, não há outro tipo de avaliar, é observar mesmo e registrar no final da aula o que o aluno alcançou" (PROFESSORA PK3b, 2020); "eu transcrevo para o papel, no final da aula, o que o aluno fez porque nós temos que fazer um registro de como ele se comportou naquele dia. Então, o meu instrumento é registrando todo o seu comportamento" (PROFESSORA PK3c, 2020).

Como já discutido anteriormente, diferentemente do Ensino Fundamental e do Ensino Médio, a avaliação na Educação Infantil caracteriza-se por uma ênfase muito maior sobre o processo do que sobre o resultado. Nesta etapa, a prática avaliativa está centrada na observação e no registro e na noção de progressão e de continuidade. Por isso, os professores procuram observar e registrar a participação das crianças nas atividades, seu grau de autonomia, suas habilidades e dificuldades, seu comportamento nas aulas, a relação com colegas e professores, a reação a conquistas e fracassos, o grau de avanço de cada criança, entre outros.

Nesta perspectiva, Oliveira (2002, p. 255) destaca que a avaliação na Educação Infantil "implica detectar mudanças em competências das crianças que possam ser atribuídas tanto ao trabalho na creche e pré-escola quanto à articulação dessas instituições com o cotidiano escolar".

Já Hoffmann (2012, p. 13) entende que a avaliação na Educação Infantil constitui, na verdade, "um conjunto de procedimentos didáticos que se estendem por um longo tempo e em vários espaços escolares, de caráter processual e visando, sempre, a melhoria do objeto avaliado". A própria LDB (Lei n 9.394/96), no seu Artigo 31, Inciso I, determina que, na Educação Infantil, a avaliação será organizada "mediante 
acompanhamento e registro do desenvolvimento das crianças, sem o objetivo de promoção, mesmo para o acesso ao ensino fundamental" (BRASIL, 1996, Art. 31).

Ao dar seguimento ao grupo focal, realizou-se a pergunta número 5: "os instrumentos avaliativos que vocês utilizam são elaborados por vocês mesmas ou elaborados pela Secretaria Municipal de Educação? Caso venham prontos, como vocês os avaliam? Atendem à realidade dos alunos?" No geral, as professoras entrevistadas concordaram que parte destes instrumentos já vem encaminhada pela SEME ou mesmo pela equipe pedagógica da própria escola. Entretanto, também existe espaço para a liberdade pedagógica do professor. Da parte da SEME, é encaminhada uma ficha de avaliação objetiva ao final de cada bimestre. No entanto, paralelamente, há o relatório de avaliação individual de cada aluno elaborado pela professora da turma. Em alguns casos, a equipe pedagógica de cada escola realiza algum tipo de acompanhamento complementar.

A respeito da elaboração da avaliação na Educação Infantil, como já foi mencionado, Hoffmann (2012, p. 19) define alguns pressupostos básicos para a avaliação nesse nível de ensino e que podem auxiliar no trabalho das equipes pedagógicas e professores:

a) uma proposta pedagógica que vise levar em conta a diversidade de interesse e possibilidades de exploração do mundo pela criança, respeitando sua própria identidade sociocultural e proporcionando-lhe um ambiente interativo, rico em materiais e situações experienciadas;

b) um professor curioso e investigador do mundo da criança, agindo como mediador de suas conquistas, no sentido de apoiá-la, acompanhála e favorecer-Ihe novos desafios;

c) um processo avaliativo permanente de observação, registro e reflexão acerca do pensamento das crianças, de suas diferenças culturais e de desenvolvimento, embasador do repensar do educador sobre o fazer pedagógico. 
Acerca das respostas apresentadas no grupo focal, na EMEIEF PK1 destacou-se a fala da Professora PK1a, e as falas das professoras PK1c, PK1e e PK1f. A professora PK1a afirma: essas avaliações já vêm prontas do município, mas elas também nos dão o direito e a oportunidade de fazer observações a respeito do aluno (PROFESSORA PK1a, 2020).

Por sua vez, as demais professoras destacaram:

Tem duas maneiras, o relatório do professor, e o que vem da Secretaria de Educação, que é bem objetivo mesmo, se alcançou ou não alcançou, se está em desenvolvimento... Bem legal e interessante e atende sim realmente à criança mesmo (PROFESSORA PK1c, 2020).

A ficha descritiva te dá mais liberdade para você acrescentar pontos que a ficha avaliativa não te dá. Você tem que pontuar: ou foi ou está em desenvolvimento ou não foi. Na descritiva, eu tenho mais liberdade, dentro do meu texto, para aplicar algumas observações necessárias na individualidade de cada criança (PROFESSORA PK1e, 2020).

A avaliação feita na ficha disponibilizada pela Secretaria de Educação é uma ficha de avaliação, porém não nos deixa livre para colocarmos, em geral, os desenvolvimentos da criança. Nós só colocamos se alcançou, se está em desenvolvimento ou não alcançou. E a ficha descritiva tem esse ponto positivo: a gente pode acrescentar algo que o aluno teve avanço (PROFESSORA PK1f, 2020).

Já as professoras PK2a e PK2b destacaram:

A ficha atende parcialmente porque ela é muito objetiva e alguns detalhes têm que ser escritos, merecem uma atenção especial, para que, quando um professor for pegar essa ficha no ano seguinte, para acompanhar uma criança, ter uma noção do desenvolvimento, em que nível de escrita essa criança está...uma preparação especial, você tem que fazer um atendimento, um plano de aula mais específico, se ela está 
no mesmo nível das outras crianças, ela sendo mais especificada, mais descrita, ela também serve como base para 0 ano seguinte (PROFESSORA PK2a, 2020).

Vem uma ficha descritiva da Secretaria de Educação para a escola para a gente avaliar no final do trimestre. Nós temos que avaliar essa criança individualmente. Atende a realidade dos alunos porque, depois, se algum pai quiser saber, nós vamos nessa ficha avaliativa para a gente saber o que foi que nós avaliamos. Está escrito ali para o resto da vida (PROFESSORA PK2b, 2020).

A esse respeito, Faria e Besseler (2014) entendem que, mais do que uma prática formalizada a ser incluída no cotidiano docente, a avaliação na Educação Infantil deve ser compreendida pela clareza de seus objetivos, a fim de enriquecer a ação pedagógica. Hoffmann (2000, p. 11), por sua vez, critica a "excessiva formalização da avaliação" e menciona que o ato de avaliar, equivocadamente, passa a "cumprir o duplo objetivo de controlar a ação do professor e o comportamento infantil", revelandose, assim, em práticas que buscam cumprir apenas uma exigência legal, o que acaba reduzindo o importante papel da avaliação nesta etapa, que é o de considerar o verdadeiro cotidiano da criança e a postura pedagógica do professor. Como exemplo a respeito disso, a autora aponta para o caso da elaboração de fichas comportamentais classificatórias semestrais, instrumento avaliativo pelo qual as crianças são classificadas em escalas comparativas, tais como: atingiu; não atingiu; muito bom; bom; fraco; etc.

Ainda sobre essa discussão, Faria e Besseler (2014) consideram importante destacar que nesta concepção de avaliação, que faz uso de fichas classificatórias, geralmente os critérios avaliativos são elaborados por alguém que não participa do dia a dia das crianças, como os diretores, os coordenadores pedagógicos ou outros profissionais da equipe de gestão com o objetivo de saber como tem sido a trajetória do aluno dentro da unidade escolar. Tais fichas são construídas de tal forma que, segundo Hoffmann (2000, p. 12-13), não dá margem para discussões e estudos sobre o assunto, por não se fundamentar em "concepções de sociedade, de educação, de 
criança, de trabalho docente e de desenvolvimento infantil" e por não contribuir para o desenvolvimento da criança e para a reflexão do trabalho do professor. A avaliação, neste contexto, acaba se transformando em "preenchimento de registros sem significado pedagógico", servindo apenas para o cumprimento burocrático.

Diante desse quadro, Zabalza (2006) ressalta a necessidade de uma cultura contrária a lógica classificatória, que conduza os educadores a rever suas ideias e práticas, de modo a produzir a tomada de consciência dos pontos fortes e fracos da atuação docente. O autor não descarta a importância da documentação e dos registros do cotidiano das crianças, mas acredita que tais instrumentos devem ser acompanhados de reflexão, como forma de possibilitar aos educadores maior sintonia entre o trabalho pedagógico e a avaliação.

Na sequência do grupo focal, destacaram-se as falas das professoras PK3a e PK3b, mas também a da Professora PK3c. As falas das duas primeiras professoras foram: "vem da Secretaria de Educação uma ficha de avaliação, são todas iguais, e no momento tem atendido à realidade dos alunos" (PROFESSORA PK3a, 2020); "a ficha vem da Secretaria de Educação, é o meio de ter o registro de um aluno, caso alguém venha a precisar, até mesmo o pai de um aluno que queira saber como o filho está, a gente tem tudo registrado ali" (PROFESSORA PK3b, 2020).

Já a fala da terceira professora, a Professora PK3c, foi a seguinte:

Já vem pronto, é um formulário padrão, em que a cada trimestre a gente vai anotando as observações a respeito de cada aluno. Eu creio que atendem sim porque tem sempre uma abertura para a gente colocar observações extras. A gente tem essa possibilidade de estar anotando além do que vem para a gente ali direcionando a gente a marcar um X. São questões objetivas. Tem essa possibilidade da gente colocar algumas características que o aluno venha a ter, a gente põe nas observações. Então eu creio que atende sim (PROFESSORA PK3c, 2020). 
Na prática, a ficha de avaliação individual dos alunos da Pré-escola da SEME consiste na inscrição, pela professora, das siglas A, ED e CNT num conjunto de 51 objetivos de aprendizagens distribuídos pelos cinco campos de experiência da Educação Infantil na BNCC. A ficha traz três colunas, uma correspondendo a cada trimestre, para a inscrição das siglas A para ALCANÇADO, ED para EM DESENVOLVIMENTO e CNT para CONTEÚDO NÃO TRABALHADO. Ao final, abaixo dos campos "data", "assinatura do professor(a)" e "assinatura do pedagogo(a)", a ficha disponibiliza o campo "observações" para a anotação de observações mais detalhadas sobre o desempenho individual de cada aluno a cada trimestre.

Dando sequência, o grupo focal realizou a pergunta número 6: "como professoras da Educação Infantil, mais especificamente da Pré-escola, vocês consideram importantes os alunos serem avaliados? Por qual motivo?" Todas as professoras, sem exceção, concordaram ser importante que os alunos sejam avaliados, sendo que algumas destacaram que a avaliação do aluno acaba servindo de parâmetro para a definição de estratégias de ação por parte do professor, como, por exemplo, a correção de lacunas de aprendizagem. A este respeito, na EMEIEF PK1, destacaramse as falas das professoras PK1a, PK1b, PK1c, PK1e e PK1f. Abrindo as falas desse momento do grupo focal, a Professora PK1a apontou: "é importantíssimo para a gente saber o que a criança alcançou para a gente trabalhar em cima do que ela não conseguiu alcançar" (PROFESSORA PK1a, 2020). Esta fala da Professora PK1a foi complementada pela Professora PK1b: "sim, é muito importante porque os professores não continuam sempre com as mesmas turmas. Por isso, quando o professor seguinte pegar a turma, ele vai saber como foi o aluno na turma anterior" (PROFESSORA PK1b, 2020). Destacando o papel da avaliação como instrumento de correção de rumos, a Professora PK1c destacou: "no decorrer do ano letivo, essa avaliação também é muito importante para que sejam tomadas atitudes para que essa criança tenha um desenvolvimento naquilo em que ela foi mal avaliada" (PROFESSORA PK1c, 2020).

Por seu turno, a Professora PK1e enfatizou: 
É importantíssimo sim para o próximo professor, no ano seguinte, ter um norte para dar continuidade ou mesmo para saber se ele precisa voltar do zero com aquele aluno para já trabalhar ir conhecendo a turminha dele porque isso vai dar para o professor um ponto de partida (PROFESSORA PK1e, 2020).

Já a Professora PK1f destacou a importância da avaliação diária:

É através da avaliação diária que a gente observa o desenvolvimento da criança, aqueles que se desenvolvem naturalmente, aqueles que precisam de apoio em sala de aula ou até mesmo aqueles que, por algum motivo, ainda não foi identificado algo (PROFESSORA PK1f, 2020).

$\mathrm{Na}$ EMEIEF PK2, as professoras manifestaram consenso em torno da ideia de que a avaliação escolar é um instrumento de correção de rumos, divergindo, no entanto, no foco. Enquanto a Professora PK2a destacou que a avaliação pode constituir um importante instrumento de autocorreção por parte do aluno, que, no caso da Educação Infantil, é a criança, a Professora PK2b apontou a importância da avaliação para a correção dos rumos do trabalho docente: "a criança, a partir do momento que ela sabe que é avaliada, procura corrigir a si própria" (PROFESSORA PK2a, 2020); "a avaliação é importante para a gente ver aquilo que precisa ser melhorado por parte do professor" (PROFESSORA PK2b, 2020).

Já na EMEIEF PK3, o consenso sobre a avaliação se deu em torno da ideia de que a avaliação escolar na Educação Infantil se trata, sobretudo, da observação da criança:

A avaliação vai além da escrita de uma ficha, passa pelo olhar diferenciado diariamente, como, no caso dos alunos que a gente observa que não enxerga direito no quadro ou no caso de alguma criança que a gente identifica algum transtorno psicológico, que a gente pode estar passando para a pedagoga (PROFESSORA PK3a, 2020). 
Eu vejo uma importância grande que os alunos sejam avaliados, mesmo que através de observações, para, posteriormente, os professores saberem quais são os conteúdos que o aluno já sabe, o que ele aprendeu e o que ele precisa aprender. Então eu vejo a necessidade de avaliar sim (PROFESSORA PK3b, 2020).

Dando prosseguimento, o grupo focal fez a pergunta número 7: "a avaliação dos alunos acrescenta ou impacta a sua prática pedagógica? Por quê?". Mais uma vez, todas as professoras concordaram. Todas afirmaram que a avaliação tanto acrescenta quanto impacta na prática pedagógica das professoras da Educação Infantil. $\mathrm{Na}$ EMEIEF PK1, as professoras PK1a, PK1b, PK1c, PK1e e PK1f afirmaram: "eu acho que acrescenta porque a gente tem uma coisa para a gente se espelhar depois. Depois, outro professor, vai pegar aquela ficha e ver o comportamento daquela criança, o que nós relatamos daquela criança (PROFESSORA PK1a, 2020); "acrescenta porque eu vou ter uma maneira de trabalhar de acordo com a realidade daquela criança, do dia a dia dela, do que ela faz, do que ela deixa de fazer, do que ela constrói ou não constrói" (PROFESSORA PK1b, 2020); "a avaliação é de extrema importância na nossa prática em sala de aula" (PROFESSORA PK1c, 2020); "acrescenta porque, ao avaliar o aluno, a gente também avalia a nossa prática" (PROFESSORA PK1e, 2020); "acrescenta sim porque aí vai ver se objetivos que a gente quis foram alcançados. Se não foi, a gente vai repensar a nossa prática pedagógica do dia a dia" (PROFESSORA PK1f, 2020).

Na EMEIEF PK2, a pergunta número 7 serviu de reflexão:

É através da avaliação dos alunos que a gente se autoavalia, que a gente observa, percebe onde tem que haver mudança. Não só os alunos precisam de um auxílio, como nós também, professores. Às vezes, passamos por situações em sala de aula que a gente precisa rever, melhorar (PROFESSORA PK2a, 2020).

Acrescenta porque a gente pode repensar a nossa prática. Se os alunos não têm tido um bom aproveitamento, a gente pode pensar, fazer uma 
autoavaliação. Será que sou eu que tenho que melhorar? Sou eu que tenho que mudar? Então, eu acho que é bom por causa disso. Pode ser que eu mude até a minha prática, de acordo com a avaliação. Então, só acrescenta. (PROFESSORA PK2b, 2020).

Na EMEIEF PK3, além da reflexão da Professora PK3b, ganhou destaque a confissão de recompensa emocional da Professora PK3c:

Acrescenta porque a gente percebe o quanto o aluno aprendeu, o quanto ele evoluiu, o quanto, em alguns casos, ele não está evoluindo, não está aprendendo. Há alunos que avançam, mas há outros que a gente só vai perceber que não estão avançando se a gente tiver um olhar avaliativo (PROFESSORA PK3b, 2020).

É muito gratificante quando chega ao final do trimestre e o professor pode colocar na ficha do aluno que ele alcançou aquele conteúdo. Isso também nos faz avaliar o nosso trabalho a partir daquele que não alcançou. $\mathrm{O}$ que eu preciso me aprimorar e o que o meu aluno precisa que eu faça diferente para que ele venha a alcançar no trimestre seguinte aquele conteúdo? É uma forma de eu estar me avaliando também (PROFESSORA PK3c, 2020).

Para finalizar, o grupo focal encerrou com a pergunta número 8: "qual a opinião de vocês sobre os instrumentos avaliativos confeccionados pela Secretaria de Municipal de Educação?". Esta, porém, foi a pergunta mais difícil porque as professoras apresentaram grande resistência em respondê-la diretamente. Na EMEIEF PK1, das sete professoras, apenas cinco se manifestaram após um pequeno intervalo de silêncio entre a pergunta e o início da primeira resposta. Transcrevendo a ordem das respostas, as falas das professoras foram as seguintes: "o relatório avaliativo da Secretaria de Educação está para passar por mudanças nos próximos anos" (PROFESSORA PK1c, 2020); "ajudou bastante, meu deu muita base, mas melhorias estão sempre acontecendo e, por isso, a avaliação pode mudar em 2020" (PROFESSORA PK1e, 2020); "no momento tem sido satisfatório porque é o que a 
gente tem, mas tem que ser muito melhorado" (PROFESSORA PK1a, 2020); "é importante a gente ver aquilo que precisa ser melhorado" (PROFESSORA PK1g, 2020); "Poderia ser uma avaliação diferente, mas eu não saberia opinar quais mudanças ou melhorias poderiam ser feitas" (PROFESSORA PK1f, 2020).

Percebeu-se, nas respostas das professoras, uma menção muito frequente ao verbo "melhorar", o que poderia sinalizar certa insatisfação com os instrumentos avaliativos confeccionados pela SEME. Talvez uma pista sobre esta insatisfação tenha sido evidenciada na fala das professoras da EMEIEF PK2, que se queixaram da falta de participação das professoras no processo de elaboração destes instrumentos avaliativos. A esse respeito, apontou a Professora PK2b: "a gente tinha que elaborar junto porque, às vezes, eles colocam algumas perguntas que não condizem com os nossos alunos. São perguntas muito fora da realidade" (PROFESSORA PK2b, 2020).

Nessa mesma direção, a Professora PK2c complementou:

Eu acho que o ideal seria desse jeito, mas nós professores, através da nossa observação e do nosso registro, fazer a nossa avaliação. A gente colocar o que o aluno avançou dentro do que pede os campos de experiência da Educação Infantil, dentro da proposta (PROFESSORA PK2c, 2020).

Ao realizar o grupo focal da EMEIEF PK3, a fim de procurar novas pistas sobre essa insatisfação das professoras, foi realizada também uma nona pergunta: "como você classifica a sua participação na elaboração dos instrumentos avaliativos? Satisfatória ou insatisfatória? E por quê?" As três professoras classificaram a própria participação como insatisfatória, sendo que apenas a professora PK3b manifestou isso diretamente: "eu classifico a nossa participação na elaboração dos instrumentos avaliativos como insatisfatória porque se eu tivesse a oportunidade de contribuir, se eles dessem uma chance para a gente poder dar a nossa opinião..." (PROFESSORA PK3b, 2020). 
Uma sugestão acerca das mudanças que poderiam acontecer na ficha de avaliação da SEME foi dada pela Professora PK3a: "acho que a ficha da Secretaria de Educação poderia sofrer alterações sim. Entendo que ela seria melhorada se fosse acrescentado um campo sobre a descrição da vida do aluno" (PROFESSORA PK3a, 2020).

Finalizando o grupo focal, a Professora PK3c sugeriu o acréscimo de um novo campo nas fichas de avaliação da SEME com observações sintetizando o histórico de cada aluno:

O professor, muitas vezes, precisa ter em mãos todo o histórico do aluno, conhecer bem o aluno. O professor precisa, muitas vezes, chegar e já estar sabendo um pouquinho do seu aluno, do que ele precisa mais. Então eu gostaria, caso pudessem ser feitas alterações, que as fichas viessem com aquele histórico que fica guardado lá na secretaria. Então, eu acrescentaria, então, um campo para isso nas fichas (PROFESSORA PK3c, 2020).

Dessa forma, as falas das professoras da EMEIEF PK3 apresentam, de maneira mais evidente, ao contrário da afirmação das professoras da EMEIEF PK1, especialmente da Professora PK1g, que explicitou que, no momento, as fichas avaliativas da SEME tem sido satisfatórias (PROFESSORA PK1g, 2020), que não apenas este modelo de avaliação da SEME não tem sido satisfatório, como também as professoras regentes da Pré-escola, que atualmente não participam do processo de elaboração das fichas avaliativas, têm muito a contribuir para o aprimoramento deste instrumento avaliativo.

Com o objetivo de complementar as respostas do grupo focal, bem como ampliar a interpretação dos resultados obtidos a partir das falas das professoras, procedeu-se a observação do espaço físico e da rotina das escolas na semana de realização do grupo focal, procurando dar maior atenção aos instrumentos avaliativos utilizados pelas professoras. 


\subsection{OBSERVAÇÕES DAS ESCOLAS}

Durante a observação das três escolas chamou a atenção a organização do espaço físico, incluindo as salas de aula, já que as escolas da Educação Infantil costumam ser decoradas de forma a atrair a atenção das crianças. Nesse caso, costuma-se encontrar nas paredes muitas cores, desenhos e murais com ilustrações, chamadas de boas-vindas e avisos muito lúdicos. Entretanto, nas três escolas observadas estes elementos não se faziam muito presentes, o que fazia as escolas parecem mais unidades escolares de Ensino Fundamental do que propriamente escolas de Educação Infantil.

No que diz respeito a rotina das escolas na semana de realização do grupo focal, em especial aos instrumentos avaliativos utilizados pelas professoras, chamou a atenção a repetição das formas de avaliação, apesar da autonomia das docentes e da liberdade para a definição dos instrumentos avaliativos além da ficha avaliativa da SEME. Todas as professoras mantêm um caderno de registro, no qual registram diariamente o desempenho individual das crianças. Entretanto, ao se observar as anotações desse caderno, percebeu-se que as professoras mais experientes se atêm mais ao comportamento dos pequenos, enquanto as mais novas dão mais atenção ao avanço no aprendizado.

Outro fato observado foi a preocupação maior das professoras mais antigas com o registro diário no caderno. Para não correr o risco de esquecimento, estas professoras já começam a realizar os registros logo no início das aulas. As professoras mais novas, por sua vez, preferem iniciar o registro nos cadernos do meio para o final do turno de aula, não dando tanta importância caso se esqueçam de realizar o registro de vez em quando.

Dessa forma, ao se observar as escolas, verificou-se falta de diversificação e de inovação nos instrumentos avaliativos utilizados, o que vai na direção contrária do que propõe a BNCC, que estimula a exploração da criatividade e a utilização de estratégias alternativas de avaliação. 
Nesse contexto, acredita-se que a busca por novas formas de avaliar na Educação Infantil, sem abandonar as práticas atualmente adotadas com base na experiência das professoras, é uma necessidade da Rede Municipal de Educação de Presidente Kennedy, até para que a Rede possa absorver aquilo que vem sendo proposto pela BNCC.

\subsection{PRODUTO FINAL}

Assim, diante dos resultados apresentados pela pesquisa, será sugerida a SEME a abertura à participação das professoras regentes na elaboração dos instrumentos avaliativos da Educação Infantil, de modo especial a ficha avaliativa trimestral. Entende-se a participação das professoras que atuam em sala de aula como fundamental, na medida em que ninguém melhor que elas conhece a realidade, as necessidades e as dificuldades e facilidades de aprendizagem dos alunos. A própria pesquisa identificou sugestões, constatando que elas têm contribuições a dar que promoveriam o aprimoramento do instrumento avaliativo utilizado.

Ao mesmo tempo, diante da constatação, pela pesquisa, da necessidade de uma formação continuada para as professoras, será apresentada a proposta de um projeto de aprimoramento profissional para que as professoras da Educação Infantil e da Préescola discutam a importância da definição dos objetivos de avaliação nessa etapa de ensino e a melhor forma de utilização de seus instrumentos na prática educativa.

Denominando-se Repensando a Avaliação Infantil conforme a BNCC, o projeto, que apresenta um prazo de execução viável dentro do calendário letivo da Rede Municipal de Educação de Presidente Kennedy, pretende, durante cinco sábados letivos entre os meses de agosto a dezembro de 2020 , ser um espaço de reflexão, de troca de experiências sobre a avaliação na Educação Infantil e de estudo coletivo da BNCC, a fim de estimular a diversificação e a inovação dos instrumentos avaliativos utilizados e de promover a renovação do currículo da Educação Infantil e o aprimoramento da prática docente na Rede Municipal de Educação de Presidente Kennedy. 
Dessa forma, pretende-se reverter toda a pesquisa realizada, apoiada financeiramente pelo PRODES/PK, em contribuição para a SEME, para a Rede Municipal de Educação de Presidente Kennedy e para toda a sociedade kenediense.

No primeiro encontro do projeto, a ser realizado com o tema "O que é avaliação escolar?", seria trazido um palestrante selecionado pela SEME para debater com as professoras sobre o conceito de avaliação e como ele se aplica ao cotidiano das escolas.

No segundo encontro, com o tema "Por que avaliar na Educação Infantil?", seria trazido um segundo palestrante selecionado pela SEME, especialista em avaliação na Educação Infantil, para discutir com as professoras os meios e métodos mais eficazes de avaliação nesta etapa educacional.

No terceiro encontro, "Como avaliar segundo a BNCC?", um terceiro palestrante selecionado pela SEME mediaria um estudo coletivo sobre a avaliação da Educação Infantil na BNCC, estimulando a reflexão sobre como aplicar a proposta da BNCC no dia a dia do trabalho em sala de aula.

No quarto encontro, "Qual a sua experiência com avaliação na Educação Infantil?”, a equipe da SEME mediaria uma troca de experiência profissional entre as próprias professoras da Rede.

Finalmente, no quinto encontro, "O que melhorar nos instrumentos avaliativos da Rede Municipal de Presidente Kennedy?", a equipe da SEME debateria com as professoras os instrumentos avaliativos utilizados pela Rede, acolhendo contribuições e construindo aperfeiçoamento coletivo com as professoras. Ao final dos encontros, um certificado poderia ser expedido pela SEME.

\section{CONSIDERAÇÕES FINAIS}

Em toda a avaliação escolar, mas especialmente na Educação Infantil os resultados da avaliação não devem ser interpretados como uma espécie de conceito final, mas como o ponto de partida para correções nas condições de ensino, visando sempre ao 
aprimoramento do conhecimento pelo aluno e a garantia do seu direito de aprendizagem. Por isso, entende-se que os resultados da avaliação devem servir a toda a comunidade escolar, como meio de orientação do trabalho da gestão, da equipe pedagógica e dos professores, bem como de informação do desempenho dos estudantes para os pais e responsáveis. Se consideradas também as avaliações externas, pode-se dizer a avaliação escolar também serve como um instrumento de informação para orientar as decisões do Poder Público, particularmente no que diz respeito às políticas educacionais.

No contexto da avaliação da Educação Infantil, pelo caráter diferenciado do tipo de estudante que esta acompanha, isto é, crianças de 0 a 5 anos, a perspectiva diagnóstica, processual e qualitativa deve ser ainda mais valorizada, primando pelo uso da observação entre seus instrumentos avaliativos.

Ao buscar compreender a percepção das professoras da Educação Infantil da Rede Municipal de Presidente Kennedy, especialmente as da Pré-escola, sobre os instrumentos avaliativos utilizados para fins de acompanhamento do desenvolvimento do aluno, a pesquisa verificou uma dificuldade de desenvolvimento da crítica e uma naturalização sobre os instrumentos avaliativos atualmente utilizados, o que acaba não conduzindo a uma reflexão da própria prática pedagógica, induzindo a uma conservação acrítica das práticas atualmente utilizadas e desestimulando a busca pela diversificação e inovação dos instrumentos avaliativos utilizados na Educação Infantil.

Quanto aos instrumentos avaliativos utilizados na Pré-escola da Rede Municipal de Presidente Kennedy, constatou-se que estes são, basicamente, a ficha avaliativa trimestral distribuída pela SEME, cuja elaboração não conta com a participação das professoras, não aproveitando a experiência dessas profissionais, e os instrumentos livremente utilizados pelas docentes, com destaque para a observação das crianças e o caderno de registro individual do progresso dos alunos.

A ficha avaliativa trimestral da SEME é individual para cada aluno da Pré-escola e consiste na inscrição, pela professora da classe, das siglas A, ED e CNT num conjunto 
de 51 objetivos de aprendizagens distribuídos pelos cinco campos de experiência da Educação Infantil na BNCC. A ficha traz três colunas, uma correspondendo a cada trimestre, para a inscrição das siglas A para ALCANÇADO, ED para EM DESENVOLVIMENTO e CNT para CONTEÚDO NÃO TRABALHADO. Ao final, abaixo dos campos "data", "assinatura do professor(a)" e "assinatura do pedagogo(a)", a ficha disponibiliza o campo "observações" para a anotação de observações mais detalhadas sobre o desempenho individual de cada aluno a cada trimestre.

Já no caderno de registro individual são registrados diariamente o progresso das crianças de acordo com a observação das professoras. Nele, as docentes procuram registrar a participação das crianças nas atividades, seu grau de autonomia, suas habilidades e dificuldades, seu comportamento nas aulas, a relação com colegas e professores, a reação a conquistas e fracassos e diante de conflitos e adversidades e o grau de avanço cognitivo e na aprendizagem.

No conjunto das respostas do grupo focal, as professoras consideraram os instrumentos avaliativos eficazes no acompanhamento da evolução individual e coletiva dos alunos da Pré-escola da Rede Municipal, porém admitiram que a ficha avaliativa trimestral da SEME poderia sofrer aperfeiçoamentos, entre eles o acréscimo de um campo para a descrição mais detalhada, pelas professoras, da progressão do aluno, não apenas no ano letivo de então, mas também do histórico dos anos letivos anteriores. $\mathrm{Na}$ opinião das docentes, isso facilitaria o trabalho tanto das professoras quanto das equipes pedagógicas das escolas, auxiliando ainda nas informações sobre o desempenho das crianças para pais e responsáveis, bem como na transição das classes e dos alunos para uma nova professora.

Dessa forma, uma importante constatação obtida no grupo focal a partir da fala das próprias professoras foi a reclamação da total ausência de participação das docentes na elaboração dos instrumentos avaliativos externos, isto é, que vem de fora da sala de aula, de modo especial a ficha avaliativa trimestral da SEME.

É por isso que, diante dos resultados da pesquisa, será sugerida a SEME a abertura à participação das professoras na elaboração dos instrumentos avaliativos da 
Educação Infantil, especialmente a ficha avaliativa trimestral. Como forma de contribuir para a recuperação da reflexão sobre o sentido pedagógico da avaliação e de estimular a discussão sobre a importância da definição dos objetivos de avaliação na Educação Infantil e a melhor forma de utilização de seus instrumentos na prática educativa, a pesquisa também apresentará uma proposta de formação continuada para o aprimoramento da formação das professoras da Educação Infantil da Rede Municipal de Presidente Kennedy.

\section{REFERÊNCIAS}

BRASIL. Ministério da Educação/Conselho Nacional de Educação. Resolução CNE/CP no 2, de 22 de dezembro de 2017. Institui e orienta a implantação da Base Nacional Comum Curricular, a ser respeitada obrigatoriamente ao longo das etapas e respectivas modalidades no âmbito da Educação Básica. Disponível em: http://basenacionalcomum.mec.gov.br/images/historico/RESOLUCAOCNE_CP222D EDEZEMBRODE2017.pdf. Acesso em 15/10/2019.

- Ministério da Educação/Secretaria de Articulação com os Sistemas de Ensino. Planejando a próxima década: conhecendo as 20 metas do Plano Nacional de Educação. Brasília: MEC, SASE, 2014. Disponível em: http://pne.mec.gov.br/images/pdf/pne_conhecendo_20_metas.pdf. Acesso em 15/10/2019.

- Ministério da Educação/Secretaria de Educação Básica. Diretrizes curriculares nacionais para a educação infantil. Brasília: MEC, SEB, 2010. Disponível em: https://ndi.ufsc.br/files/2012/02/Diretrizes-Curriculares-para-a-E-I.pdf. Acesso em 02/09/2019.

BRASIL. Presidência da República. Constituição da República Federativa do Brasil de 1988. Disponível em: http://www.planalto.gov.br/ccivil_03/constituicao/ constituicao.htm. Acesso em 02/09/2019. 
BRASIL. Presidência da República. Lei no 9.394, de 20 de dezembro de 1996. Estabelece as diretrizes e bases da educação nacional. Disponível em: http://www.planalto.gov.br/ccivil_03/leis/19394.htm. Acesso em 02/09/2019.

FARIA, A. P.; BRESSELER, L. H. A avaliação na Educação infantil: fundamentos, instrumentos e práticas pedagógicas. Nuances: estudos sobre Educação, Presidente Prudente-SP, v. 25, n. 3, p. 155-169, set./dez. 2014.

FERREIRO, E.; TEBEROSKY, A. Psicogênese da língua escrita. Porto Alegre: Artes Médicas, 1984.

HOFFMANN, J. Avaliação e educação infantil: um olhar sensível e reflexivo sobre a criança. Porto Alegre: Mediação, 2012.

Avaliação mediadora: uma prática em construção da pré-escola à universidade. Porto Alegre: Mediação, 1993.

Avaliação na pré-escola: um olhar sensível e reflexivo sobre a criança. Porto Alegre: Mediação, 2000.

IBGE - FUNDAÇÃO INSTITUTO BRASILEIRO DE GEOGRAFIA E ESTATÍSTICA. Estimativas de População em 01/07/2019. 2019. Disponível em: https://www.ibge.gov.br/estatisticas-novoportal/sociais/populacao/9103-estimativasde-populacao.html?=\&t=downloads. Acesso em 10/10/2019.

INEP - INSTITUTO NACIONAL DE ESTUDOS E PESQUISAS EDUCACIONAIS ANÍSIO TEIXEIRA. Censo Escolar: Resultados e Resumos. 2018. Disponível em: http://portal.inep.gov.br/resultados-e-resumos. Acesso em 27/10/2019.

. Ideb - Índice de Desenvolvimento da Educação Básica: Resultados e Metas 2015. 2015. Disponível em: http://ideb.inep.gov.br/. Acesso em 13/10/2019.

Ideb - Índice de Desenvolvimento da Educação Básica: Resultados e Metas 2017. 2017. Disponível em: http://ideb.inep.gov.br/. Acesso em: 13/10/2019. 
LIBÂNEO, J. C. A prática pedagógica de professores da escola pública. 1982. Dissertação (Mestrado em Filosofia da Educação), Pontifícia Universidade Católica de São Paulo, São Paulo.

LUCKESI, Carlos Cipriano. Avaliação da aprendizagem escolar. 3 ed. São Paulo: Cortez, 1996.

MICARELLO, H. Avaliação e transições na educação infantil. S.I.: Portal MEC, 2010. Disponível em: http://portal.mec.gov.br/index.php?ltemid=\&gid=6671\&option= com_docman\&task=doc_download. Acesso em 15/10/2019.

OLIVEIRA, Z. M. R. de. Educação infantil: fundamentos e métodos. São Paulo: Cortez, 2002. (Docência em formação).

PRESIDENTE KENNEDY - ES. História do município. 2019. Disponível em https://www.presidentekennedy.es.gov.br/pagina/ler/1000/historia. Acesso em 25/10/2019.

PROFESSORAS PK1a a PK1g. Entrevista para a pesquisa de Dissertação de Mestrado "Avaliação na aprendizagem da Educação Infantil: um estudo de caso no município de Presidente Kennedy-ES", desenvolvida na Faculdade Vale do Cricaré. [mar. 2020]. Entrevistadora: Hilda Angélica L. Fontana Gomes. Presidente Kennedy, 2020 (.mp3).

PROFESSORAS PK2a a PK2b. Entrevista para a pesquisa de Dissertação de Mestrado "Avaliação na aprendizagem da Educação Infantil: um estudo de caso no município de Presidente Kennedy-ES", desenvolvida na Faculdade Vale do Cricaré. [mar. 2020]. Entrevistadora: Hilda Angélica L. Fontana Gomes. Presidente Kennedy, 2020 (.mp3).

PROFESSORAS PK3a a PK3b. Entrevista para a pesquisa de Dissertação de Mestrado "Avaliação na aprendizagem da Educação Infantil: um estudo de caso no município de Presidente Kennedy-ES", desenvolvida na Faculdade Vale do 
Cricaré. [mar. 2020]. Entrevistadora: Hilda Angélica L. Fontana Gomes. Presidente Kennedy, 2020 (.mp3).

RIBEIRO, S. C. A Pedagogia da Repetência. Estudos Avançados, São Paulo, v. 5, n. 12, p. 07-21, maio/ago. 1991.

SILVA, J. P. da; URT, S. da C. Educação infantil e avaliação: uma ação mediadora. Nuances: estudos sobre Educação, Presidente Prudente-SP, v. 25, n. 3, p. 56-78, set./dez. 2014.

TYLER, R. W. Princípios básicos de currículo e ensino. Porto Alegre: Globo, 1974.

ZABALZA, M. A. Qualidade em Educação Infantil. Porto Alegre: Artmed, 2006.

\section{APÊNDICE - REFERÊNCIAS DE NOTA DE RODAPÉ}

3. A Lei no 9.394/96 (Lei de Diretrizes e Bases da Educação Nacional - LDB), no seu Artigo 31, Inciso I, determina que a avaliação, na Educação Infantil, será organizada "mediante acompanhamento e registro do desenvolvimento das crianças, sem o objetivo de promoção, mesmo para o acesso ao ensino fundamental" (BRASIL, 1996, Art. 31).

4. A Meta 1 do Plano Nacional de Educação estabeleceu a universalização, até 2016, da educação infantil na Pré-escola para as crianças de 4 a 5 anos de idade e a ampliação da oferta de Educação Infantil em Creches, de forma a atender, no mínimo, $50 \%$ das crianças de até 3 anos e, assim, garantir o direito de aprendizagem das crianças estabelecido na Constituição Federal de 1988, no seu Artigo 6ำ (BRASIL, 2014; BRASIL, 1988, Art. 6º).

5. O prazo para a adequação dos sistemas e redes de ensino à BNCC da Educação Infantil e do Ensino Fundamental, segundo o Parágrafo Único, do Artigo 15, da Resolução CNE/CP no 2/2017, é o início do ano letivo de 2020 (BRASIL, 2017, Art. 15). 
6. No sentido de behaviorista, termo proveniente do conjunto de abordagens, nascidas entre os séculos XIX e XX, dentro da Psicologia, que defendem o comportamento observável como objeto de estudo, com ênfase nos fatos objetivos (estímulos e reações), sem fazer recurso à introspecção.

7. Libâneo (1982), em seu estudo sobre a prática pedagógica dos professores das escolas públicas de São Paulo, demonstrou que a avaliação da aprendizagem é o âmbito da ação pedagógica em que os professores são mais resistentes à mudança.

8. Com base nos dados do Censo Escolar e do Serviço de Estatística do Ministério da Educação, Ribeiro (1991) calculou que, no início da década de 80, o sistema educacional brasileiro chegava a repetir seis em cada dez crianças na primeira série do Ensino Fundamental, fato que desmistifica a visão de que as crianças, no Brasil, abandonam precocemente a Escola por motivos de ordem social ou cultural. No referido estudo, o autor concluiu que as famílias mais pobres fazem um grande esforço para que seus filhos permaneçam na escola e que é a péssima qualidade da escola que impede, através da repetência, a universalização da educação fundamental da população brasileira.

9. Avaliação classificatória é aquela segundo a qual os alunos são classificados e comparados a partir de "notas, conceitos, estrelinhas, carimbos" (HOFFMANN, 1993, p. 87), a fim de determinar se o aluno é ótimo, bom, regular ou ruim. Para Hoffmann (1993), o ato de avaliar na perspectiva classificatória volta-se para o aspecto disciplinador e punitivo, impossibilitando a reflexão sobre o processo de construção dos conhecimentos e das aprendizagens.

10. Os Anos Iniciais do Ensino Fundamental compreendem do $1^{\circ}$ (antiga Alfabetização) ao 5ํAno (antiga 4ª Série).

11. Professor regente é como são chamados os professores que ministram aulas, isto é, que são regentes de sala de aula. A legislação municipal de Presidente Kennedy utiliza explicitamente esta denominação em sua normatização, como se pode verificar no seguinte endereço, que concentra as publicações da Secretaria Municipal de 
Educação

(SEME):

$<$ https://www.presidentekennedy.es.gov.br/transparencia/documento/index/

0 ?tipo=6003 . Acessado em: 26 out. 2019.

12. A compreensão das professoras (e também das equipes pedagógicas, unidades escolares e redes de ensino) acerca do nível de avanço do desenvolvimento dos alunos, bem como a autonomia para avaliar esse avanço, apoia-se nos princípios de liberdade de cátedra e de autonomia pedagógica, garantidos pelo Artigo 206 da Constituição Federal de 1988 e pelo Artigo 15 da LDB (Lei no 9.394/96), não estando, portanto, balizada pela reflexão acadêmica de nenhum autor.

13. Na obra "Psicogênese da Língua Escrita", as autoras Ferreiro e Teberosky (1984) argumentam que toda criança passa por quatro fases até que esteja alfabetizada. A primeira fase é a pré-silábica, quando a criança ainda não consegue relacionar as letras com os sons da língua falada. A segunda fase é a silábica, quando a criança interpreta a letra à sua maneira, atribuindo valor de sílaba a cada uma. A terceira fase é a silábico-alfabética, que mistura a lógica da fase anterior com a identificação de algumas sílabas. A quarta fase, por sua vez, é a alfabética, quando a criança, enfim, domina o valor das letras e sílabas. Nos anos 1980, as ideias das duas autoras provocaram no Brasil grande impacto em relação a concepção que se tinha do processo de alfabetização, influenciando os Parâmetros Curriculares Nacionais.

14. O Programa de Desenvolvimento do Ensino Superior e Técnico no Município de Presidente Kennedy (PRODES/PK) oferta bolsas para quem deseja qualificação, de forma integral ou parcial. Os critérios básicos para a aceitação do pedido de bolsa têm relação com a renda per capita do candidato, que pode variar de acordo com o curso pretendido. Mais detalhes no endereço $<$ https://www.presidentekennedy.es.gov.br/noticia/ler/2560/secretaria-de-educacaolanca-edital-para-recadastro-no-prodes-2020-1>.

15. Refere-se a média aritmética simples, obtida a partir do total do tempo de experiência das professoras (em meses) dividido pelo total do número de professoras. 
Enviado: Junho, 2020.

Aprovado: Junho, 2020. 